\title{
New critical values for $F$ and their use in the ANOVA and Fisher's $F$ tests for evaluating geochemical reference material granite G-2 (U.S.A.) and igneous rocks from the Eastern Alkaline Province (Mexico)
}

\author{
Nuevos valores críticos de $\mathrm{F}$ y su uso en las pruebas ANOVA y $\mathrm{F}$ de Fisher para evaluar \\ el material de referencia geoquímica del granito G-2 (U.S.A.) y rocas ígneas de la \\ Provincia Alcalina Oriental (México)
}

\author{
R. Cruz-Huicochea ${ }^{1}$, S.P. Verma ${ }^{2 *}$ \\ ${ }^{1}$ Posgrado en Ingeniería (Energía), Instituto de Energías Renovables, Universidad Nacional Autónoma de México, Priv. \\ Xochicalco s/no., Col. Centro, Apartado Postal 34, Temixco 62580, Morelos, México.recrh@live.com \\ ${ }^{2}$ Departamento de Sistemas Energéticos, Instituto de Energías Renovables, Universidad Nacional Autónoma de México, Priv. \\ Xochicalco s/no., Col. Centro, Apartado Postal 34,Temixco 62580,Morelos, México.spv@ier.unam.mx \\ *corresponding author
}

Received: 16/05/2011 / Accepted: 12/04/2013

\begin{abstract}
Monte Carlo method was used to simulate precise and accurate critical values (with 2 to 7 decimal places) of Fisher's $\mathrm{F}$ test for degrees of freedom $\left(v_{1}\right.$ and $v_{2}$ ) of up to 2000 and confidence levels of $20 \%$ to $99.9 \%$ for two-sided or two-tailed test (or equivalently to $60 \%$ to $99.95 \%$ for one-sided or one-tailed test). Unlike the existing literature, we present 15 new critical value tables along with 15 additional tables of the error estimates of individual values. For the two degrees of freedom - horizontal $\left(v_{1}\right)$ as well as vertical $\left(v_{2}\right)$-the critical values orrespond to 1(1)30(5)100(10)160(20)200(50)400(100)1000 and 6(1)30(5)100(10)160(20)200(50)400 (100)1000(200)2000, respectively, where the numbers before and after the parenthesis are the initial and final values for which critical values were simulated and the numbers in parenthesis indicate the step size how the initial value of degrees of freedom approached to the final one. Thus these critical values consist of $62 \times 62$ values for each of the eleven confidence levels. Even though a large number (3844 for each confidence level, amounting to a total of 42284 values for all confidence levels) of new values of $\mathrm{F}$ were simulated, values do not exist for many different degrees of freedom in the range of 1-2000. This problem of unavailable critical values was resolved by evaluating regression models based on simple polynomial functions as well as those involving logtransformation of the independent variable. New best-fit equations were thus proposed to estimate the not-tabulated critical values as well as for the estimation of probability of calculated $\mathrm{F}$ value. This methodology of log transformations should be useful also for other kinds of applications involving polynomial fitting. We compared these simulated results with commercial as well as freely available software. The new precise and accurate critical values were used to illustrate the application of analysis of variance (ANOVA) and Fisher's F tests to geochemical data for international geochemical reference material granite G-2 from U.S.A. We also present the methodology to statistically compare geochemical data for ultrabasic, basic and intermediate magmas from eight regions of the Eastern Alkaline Province of Mexico and U.S.A. Finally, we use these as well as the discordant outlier-free data for ultrabasic and basic rocks in multi-dimensional discrimination diagrams to explore the tectonic setting for this volcanic province, which was inferred to be mainly an extensional zone or a continental rift.
\end{abstract}


Keywords: Monte Carlo simulation, significance test, polynomial regressions, natural logarithm-transformation, discrimination diagrams, discordant outliers.

\section{Resumen}

El método de Monte Carlo fue usado para simular valores críticos precisos y exactos (con 2 a 7 puntos decimales) de la prueba F de Fisher para los grados de libertad $\left(v_{1}\right.$ y $\left.v_{2}\right)$ hasta 2000 y niveles de confianza de $20 \%$ a $99.9 \%$ para la prueba de dos colas o ambos lados (o en forma equivalente de $60 \%$ a $99.95 \%$ para la prueba de una cola o un sólo lado). A diferencia de la literatura existente, presentamos 15 nuevas tablas de valores críticos junto con otras 15 tablas adicionales con las estimaciones de errores de los valores individuales. Para los grados de libertad, horizontal $\left(v_{1}\right)$ y vertical $\left(v_{2}\right)$, los valores críticos corresponden a $1(1) 30(5) 100$ (10)160(20)200(50)400(100)1000 y 6(1)30(5)100(10)160(20)200(50)400(100)1000(200)2000, respectivamente, donde los números antes y después del paréntesis son los valores iniciales y finales para los cuales los valores críticos fueron simulados y el número en el paréntesis indica el escalón cómo el valor inicial del grados de libertad llega al valor final. De esta manera, estos consisten en 62x62 valores para cada nivel de confianza. A pesar de que un gran número (3844 para cada nivel de confianza, lo que equivale a un total de 42284 valores para todos los niveles de confianza) de nuevos valores de F fueron simulados, no se dispone de valores correspondientes a muchos grados de libertad intermedios entre el 1 y 2000 . Este problema de valores críticos no-disponibles fue resuelto mediante la evaluación de modelos de regresión basados en métodos convencionales de polinomios así como aquellos con las transformaciones logarítmicas de la variable independiente. La metodología de transformaciones logarítmicas debe ser útil también para otros tipos de aplicaciones de ajustes polinomiales. Se proponen nuevas ecuaciones para la estimación de los valores críticos no tabulados, así como para la estimación de la probabilidad del valor de F calculado. Así mismo, comparamos los resultados con software comercial y de libre acceso. Estos nuevos valores críticos más precisos y exactos fueron usados para ilustrar la aplicación de las pruebas de análisis de varianza (ANOVA) y $\mathrm{F}$ de Fisher a los datos geoquímicos de material internacional de referencia geoquímica granito G-2 de E.U.A. También presentamos la metodología de comparar estadísticamente los datos geoquímicos para magmas ultrabásicos, básicos e intermedios de ocho regiones de la Provincia Alcalina Oriental de México y E.U.A. Finalmente, usamos estos datos y los libres de valores extremos discordantes para rocas ultrabásicas y básicas en diagramas tectonomagmáticos multi-dimensionales para explorar el ambiente tectónico de esta provincia volcánica, mismo que fue inferido principalmente como una zona de extensión o rift continental.

Palabras clave: Simulación Monte Carlo, pruebas de significancia, regresión polinomial, transformación logarítmica natural, diagramas de discriminación, valores extremos discordantes.

\section{Introduction}

Any experimental measurement should be characterised by at least two statistical parameters - central tendency or location and dispersion or scale (e.g., Ebdon, 1988; Barnett and Lewis, 1994; Jensen et al., 1997; Bevington and Robinson, 2003; Miller and Miller, 2005; Verma, 2005). The use of sample mean value for the former and sample standard deviation for the latter is common in geological literature. In geological or geochemical discussion, it is frequently necessary to compare measurements of a given geochemical parameter from two geological areas or rock formations, for which two mean values are simply compared visually, and inference in made about one mean value is higher, lower, or different from the other, without any reference to the corresponding dispersion estimates. This is a statistically erroneous practice and should be replaced by the proper so called significance tests (e.g., Verma, 2005, 2012a, 2013a), although these tests should be strictly applied to log-transformed compositional data (e.g., Aitchison, 1986). These significance tests are as follows: Fisher's F test, Student's t test, and ANOVA (ANalysis $O$ f $V A$ riance). The simulation of new critical values for the $t$ statistic and their applications are extensively discussed in the companion paper by Verma and Cruz-Huicochea (2013) in this Monograph.

The Fisher's F test is generally applied for the comparison of variances of two statistical samples drawn from a normal (or Gaussian) distribution, which allows us to choose the appropriate equation for the application of the Student's t test (e.g., Ebdon, 1988; Verma, 2005). More importantly, the ANOVA test is a powerful procedure to evaluate if three or more statistical normal samples are drawn from one or more populations (e.g., Jensen et al., 1997; Bevington and Robinson, 2003; Miller and Miller, 2005; Verma, 2005).

Evaluation of hypotheses by these tests ( $\mathrm{F}$ and ANOVA) requires that the calculated statistic be compared with the corresponding critical value at the chosen confidence or significance level. At present, critical value tables are available for confidence levels of $95 \%$ and $99 \%$ (or equivalently, significance levels of $5 \%$ and $1 \%$, or $\alpha$ of 0.05 and 0.01 , respectively, and for horizontal degrees of freedom ( $v_{1}$ for the numerator of the statistic) of 1(1)12(3)15(5)30(10)50, 100, 1000 and $\infty$, and for vertical degrees of freedom $\left(v_{2}\right.$ for the denominator of the statistic) of 1(1)30, 35, 40, 50, 60, 80, 100, 200, 500, 1000 and $\infty$, and have the precision of two or three decimal 
places (e.g., Neave, 1981; Morrison, 1990; Kanji, 1993; Miller and Miller, 2005; Verma, 2005; Walker and Maddan, 2005). Note in the above sequences that the numbers within the brackets "()" represent the step size and those outside them are the initial and final values of the degrees of freedom. Thus, critical values are available for all degrees of freedom $v_{1}$ from 1 to 12 , but for higher $v_{1}$ only for $v_{1}=15,20,25,30,40,50,100,1000$, and $\infty$. For critical values not tabulated, interpolations are required such as those proposed by Verma (2009). Nevertheless, software systems have been developed to generate more precise critical values from the density function of the $\mathrm{F}$ distribution; this is the case of the $\mathrm{R}$ Development Core Team (2009).

Multivariate techniques, such as linear discriminant analysis, require the data to be drawn from a multivariate normal distribution (e.g., Morrison, 1990). Barnett and Lewis (1994) and Rencher (2002) provided details on the Wilks' statistic (Wilks, 1963) for detecting single or more outliers in a multivariate normal distribution. They also indicated that the critical values by Wilks (1963) are only approximate. Jennings and Young (1988) simulated more precise critical values for one or more outliers in such multivariate distributions. However, these critical value tables are limited to sample sizes of 5(1)10(2)20(5)50, $100,200,500$ (where the numbers before and after the parenthesis are the initial and final values and the numbers in parenthesis indicate the step size). Thus, the expression " $5(1) 10(2) 20$ " means that the critical values are available for multivariate sample sizes of $5,6,7,8,9,10$, $12,14,16,18$, and 20 . In the absence of critical values for sample sizes not tabulated in any existing work, for example, for sample size of 11,13 , or 15 , the Wilks' test cannot be easily applied, beause precise interpolations are required. Rencher (2002) also presented the equations to convert the Wilks' statistic to the F test statistic. Therefore, in the absence of a complete set of critical values for all sample sizes, in spite of the fact that Jennings and Young (1988) had simulated more tables in addition to the approximate values by Wilks (1963), the new critical values for the $\mathrm{F}$ test can be advantageously used for identifying and separating discordant outliers in multivariate normal distributions.

In this work, we developed an alternative Monte Carlo method to simulate precise and accurate critical values for ANOVA and $\mathrm{F}$ tests and natural logarithm-transformation based polynomial regressions for the interpolation of simulated values and calculation of sample probabilities. Our results are favourably compared with the commercially and freely available software systems. We illustrate the use of these critical values for the evaluation of the geochemical reference material granite G-2 from U.S.A. and of geochemical data for volcanic rocks from the Eastern Alkaline Province (EAP) of Mexico and U.S.A. Finally, the geochemical data for ultrabasic and basic rocks from the EAP were also used in multi-dimensional tectonomagmatic discrimination diagrams to infer its dominant tectonic setting of extension or continental rift.

\section{Alternate procedure}

\subsection{Simulation of critical values for the ANOVA and F tests}

Monte Carlo method has been used in Mexico to simulate precise and accurate critical values of discordancy tests (Verma and Quiroz-Ruiz, 2006a, 2006b, 2008, 2011; Verma et al., 2008) and Student' t test (also known as tstatistic; Verma and Cruz-Huicochea, 2013) as well as for other applications such as the evaluation of nuclear reactor performance (Espinosa-Paredes et al., 2010) and error propagation in ternary diagrams and alternative proposal of bivariate diagrams based on log-ratio transformations (for advantages and requirements of such transformations, see Verma, 2012a and references therein). Our procedure is similar to that described by Verma and QuirozRuiz (2006a) and Verma and Cruz-Huicochea (2013); therefore, only the differences of the present approach will be specifically mentioned.

\subsubsection{Optimum simulation size or repetitions}

The mean critical values for $95 \%$ and $99 \%$ confidence levels and associated standard errors were calculated for degrees of freedom $v_{1}$ of 5 and 10 and $v_{2}$ of 10, 20, and 30 , using seven different simulation or repetition sizes of 10,000 to $5^{\prime} 000,000$ and 100 independent streams of normal random variates IID N $(0,1)$. The standard error of the mean significantly decreased with increase in the repetition sizes from 10,000 to 1'000,000, but remained practically constant for higher repetitions (from 1'000,000 to $5 ' 000,000)$. Therefore, for routine simulations we used the repetitions of 1'000,000 and 100 independent streams of random normal variates.

\subsubsection{Calculation of the statistic}

The F statistic was calculated for each set of degrees of freedom $v_{1}$ and $v_{2}$ where $v_{1}=\left(n_{x}-1\right)$ and $v_{2}=\left(n_{y}-1\right)$, for which 1'000,000 samples of sizes $n_{x}$ and $n_{y}$ were simulated from each of the 100 streams. The ANOVA statistic was calculated for each set of $v_{1}$ and $v_{2}$ where $v_{1}=[k-1]$ and $v_{2}=[\mathrm{N}-k], k$-number of samples and $\mathrm{N}$-total number of data in all $k$ samples, for which $k$ samples for appropriate combination of sizes were simulated, each of them 
$1,000,000$ times. For example, for $v_{1}=4$ and $v_{2}=20, k=5$ samples had to be simulated with the total number of data $\mathrm{N}$ as $v_{2}+k=25$ and the number of data in each sample as $\mathrm{N} / \mathrm{k}=5$.

\subsubsection{Calculation of the critical values}

The simulated values correspond to the following degrees of freedom: horizontal $v_{1}$ of 1(1)30(5)100(10)160( 20)200(50)400(100)1000 and vertical $v_{2}$ of 6(1)30(5)100 (10)160(20)200(50)400(100)1000(200)2000. The confidence levels (two-tailed or two-sided) were as follows: $20 \%, 40 \%, 50 \%, 60 \%, 70 \%, 80 \%, 90 \%, 95 \%, 96 \%, 98 \%$, $99 \%, 99.5 \%, 99.6 \%, 99.8 \%$ and $99.9 \%$, which correspond to the significance levels $\alpha=0.80,0.60,0.50,0.40,0.30$, $0.20,0.10,0.05,0.04,0.02,0.01,0.005,0.004,0.002$, and 0.001 , respectively (two-tailed or two-sided). These values correspond respectively to the following confidence levels of one-tailed or one-sided test: $60 \%, 70 \%$, $75 \%, 80 \%, 85 \%, 90 \%, 95 \%, 97.5 \%, 98 \%, 99 \%, 99.5 \%$, $99.75 \%, 99.8 \%, 99.9 \%$ and $99.95 \%$, which correspond to the significance levels $\alpha=0.40,0.30,0.25,0.20,0.15$, $0.10,0.05,0.025,0.02,0.01,0.005,0.0025,0.002,0.001$, and 0.0005 , respectively (one-tailed or one-sided).

Finally, the mean and standard error of the mean of the 100 values for each $v_{1}$ and $v_{2}$ and each confidence level, were estimated and reported.

\subsection{Interpolation of critical values for the ANOVA and $F$ tests}

As in Verma (2009) and Verma and Cruz-Huicochea (2013), for estimating the interpolated critical values (not tabulated) the natural logarithm-transformation of both $v_{1}$ and $v_{2}$ was a necessary step before the polynomial regressions. A computer program was written in Java that enabled us to evaluate 28 different regression models based on simple polynomial fits as well as single, double and triple natural logarithms of $v_{1}$ and $v_{2}$, all up to $8^{\text {th }}$ order polynomial terms. The best-fit equation was chosen from the criteria of the multiple-correlation coefficient $\left(\mathrm{R}^{2}\right)$ and the averaged sum of the squared residuals (SSR/N where $\mathrm{N}$ is the total number of residuals).

\subsection{Polynomial fits for the estimation of confidence lev- els for the ANOVA and F tests}

Computational packages, both commercial and freely available, do calculate the confidence level that corresponds to a given set of statistical samples, but the actual method used is not clear. Therefore, we developed a similar polynomial fitting method as for the interpolation of critical values. This consisted of the natural logarithm transformations of degrees of freedom as well as polynomial terms up to $8^{\text {th }}$ order.

\section{Results of Monte Carlo simulations}

\subsection{Critical value tables}

We simulated 100 sets of critical values for 62 values of $v_{1}$ as 1(1)30(5)100(10)160(20)200(50)400(100)1000 and also 62 values of $v_{2}$ as 6(1)30(5)100(10)160(20)20 0(50)400(100)1000(200)2000 and for confidence levels (two-tailed or two-sided) of 20\%, 40\%, 50\%, 60\%, 70\%, $80 \%, 90 \%, 95 \%, 96 \%, 98 \%, 99 \%, 99.5 \%, 99.6 \%, 99.8 \%$ and $99.9 \%$.

The standard error of the mean calculated from these 100 sets of values was used as the criterion for reporting rounded critical values (Bevington and Robinson, 2003; Verma, 2005). The newly simulated critical values, although more precise than the tabulated critical values in the literature, are consistent with the literature values as well as with those generated from the language R (R Development Core Team, 2009). Abridged form of the mean values for the most frequently used $95 \%$ and $99 \%$ confidence levels (two-tailed and one-tailed) are presented in Tables 1-4 (Appendix A - Supplementary material), respectively, and the respective standard error values in Tables 5-8 (Appendix A - Supplementary material). These values are for the horizontal $v_{1}$ of 1-11 only, but for all vertical degrees of freedom $v_{2}$ simulated in this work, $i$. e.,6(1)30(5)100(10)160(20)200(50)400(100)1000(200)2 000 .

The complete simulated critical values for all confidence levels and all $v_{1}$ and $v_{2}$ (360 pages of tables; Tables ES1-ES15 and ES16-ES30, respectively, for mean values and their standard errors) are available on request to any of the authors as a supplementary file in pdf format. The complete critical value tables for all simulated $v_{1}$ and $v_{2}$ corresponding to partial Tables 1-4 are, respectively, Tables ES8, ES7, ES11, and ES10. Similarly, the complete standard error tables corresponding to Tables 5-8 are, respectively, Tables ES23, ES22, ES26, and ES25.

\subsection{Critical value equations}

For the critical values not tabulated, the regression equations based on 28 different models were tested for the most frequently used confidence levels of $95 \%$ and $99 \%$. The best models were obtained in this work (i.e., with the lowest $\mathrm{R}^{2}$ and SSR/N; for more details on these criteria, the reader is referred to a companion paper by Verma and Cruz-Huicochea, 2013, in this Monograph). A few regression equations are presented in Tables 9 and 10 (Appendix A - Supplementary material) for one-tailed 
$95 \%$, to estimate, respectively, the missing values of $v_{2}$ for given $v_{1}$ of 1-11 only and the missing values of $v_{1}$ for given $v_{2}$ of 6-17. Similar equations for $99 \%$ confidence levels and similar $v_{1}$ and $v_{2}$ are summarized in Tables 11 and 12 (Appendix A - Supplementary material). A large number of equations are summarised in Tables ES31ES35 (now 25 pages of tables; more tables for other degress of freedom are being prepared; all will be available on request from any of the authors).

\subsection{Equations for probability estimates}

In an analogous manner, 21 regression models were evaluated to propose equations (as examples in Table ES35 (available from any of the authors) for estimating probability of statistical samples for the ANOVA and $\mathrm{F}$ tests. In fact, here we converted the probabilities to confidence levels in order to make the probability estimates more understandable to scientists working in different disciplines (other than mathematics or statistics). In the teaching experience of the second author of this paper, most students and researchers, if not all, do not fully understand the use of commercial or freely available software, being the reason why he clarified these concepts in Verma (2005), and we converted the estimates to confidence levels. For using these equations, the parameter "cv" should be replaced by the calculated value of ANOVA or F statistic $\left(\mathrm{F}_{\text {calc }}\right)$ for the set of statistical samples, for which the probability estimate or confidence level is desired.

\section{Applications}

It is important to use statistical tests for processing geochemical data to evaluate similarities and differences among several compositional variables. The erroneous practice of simply comparing only the mean values without any reference to the standard deviation estimates should be abondoned (Verma, 2012a, 2013).

We exemplify the application of the ANOVA (for three or more statistical samples) and Fisher's F and Student's $\mathrm{t}$ (both for two statistical samples) tests, using the new critical values for $\mathrm{F}$ (this work) and $\mathrm{t}$ (Verma and CruzHuicochea, 2013). These significance tests also require that the individual data arrays (statistical samples under evaluation) be drawn from a normal distribution (Morrison, 1990). To ascertain this assumption, we used only the multiple-outlier type tests (Barnett and Lewis, 1994; González-Ramírez et al., 2009; Verma et al., 2009) programmed in DODESSYS (Verma and Díaz-González, 2012) for identifying and separating discordant outliers at the strict $99 \%$ confidence level. We applied the ANO$\mathrm{VA}$ and $\mathrm{F}$ tests both before and after the application of
DODESSYS. We also note that our application examples were processed in an earlier version of a computer program for the application of significance tests, which used our earlier less precise critical values for F. This is the reason why the critical values in our examples may not totally match with those in Tables 1-4 (Appendix A - Supplementary material).

Two application examples are presented as follows: (i) geochemical data for international geochemical reference material granite G-2 from U.S.A. and (ii) geochemical data for volcanic rocks from the Eastern Alkaline Province (EAP) of Mexico and U.S.A. For the application of significance tests, strictly speaking only logratios should be used (e.g. Aitchison, 1986; Verma, 2012a, 2013). However, we present the examples of chemical compositions, as is still customary in the geological literature.

\subsection{Evaluation of geochemical data for international reference material granite $G-2$}

We used an unpublished compilation of geochemical data for G-2 as done by Verma and Cruz-Huicochea (2013) in a companion paper of this Monograph. This application therefore will allow the user to compare the results of application of ANOVA (this work) with the combined application of $\mathrm{F}$ and $\mathrm{t}$ tests (Verma and Cruz-Huicochea, 2013). Although it is customary to present major-element data as oxides, we have shown them as elements, because the compilation by Gladney et al. (1992), which lists the data as elements, was used initially. Thus, because these authors had compiled the major-elements as elements $(\%)$, we continued their "unconventional" approach in this work.

The method grouping was the same as that proposed by Velasco-Tapia et al. (2001) as follows: Gr1-classical methods; Gr2-atomic absorption methods; Gr3-xray fluorescence methods; Gr4-emission spectrometry methods; Gr5-nuclear methods; Gr6-mass spectrometry methods; Gr7-chromatography methods; and Gr8-miscellaneous methods.

In the processing of reference materials, the geochemical data from different analytical methods should only be combined after ascertaining that these data were drawn from a single or equivalent normal population (Verma, 1998). Therefore, we maintained the identity of different analytical method groups (Gr1 to Gr8) and applied the significance tests of ANOVA or the combination of $\mathrm{F}$ and $\mathrm{t}$, to first evaluate the similarities and differences among these data arrays. When these tests suggested that a certain number of groups were drawn from the same population, i.e., they did not show statistically significant differences, they were combined to propose final mean values for the granite G-2 under evaluation. 
Table 13 (Appendix A - Supplementary material) presents ANOVA results for 10 major-elements (Si to P, all in \%), 13 rare-earth elements ( $\mathrm{La}$ to $\mathrm{Lu}$ ), and 33 other trace elements ( $\mathrm{B}$ to $\mathrm{W})$. The calculated $\mathrm{F}$ value $\left(\mathrm{F}_{\text {calc }}\right)$ and critical $\mathrm{F}$ value $\left(\mathrm{F}_{\text {crit }}\right)$ for the corresponding degrees of freedom $\left(v_{1}\right.$ and $\left.v_{2}\right)$ and the total number of groups for a given element can be used to test the null hypothesis $\left(\mathrm{H}_{0}\right)$ that the data from all method groups were drawn from a single population at the $99 \%$ confidence level, as compared to the alternate hypothesis $\left(\mathrm{H}_{1}\right)$, according to which the data from all method groups did not arise from the same population. Although in some books such as Miller and Miller (2005) ANOVA is applied in conjunction with the one-sided critical values, we opted to apply this test using two-sided values, because for the alternate hypothesis to be true or accepted the mean or variance, or both for one or more samples under evaluation can be either smaller or greater, i.e., different from the remaining samples. It is only for the other significance tests, namely $\mathrm{F}$ and $\mathrm{t}$, that a suitable hypothesis for one-sided values can be proposed, for example, for F test the alternate hypothesis could be that one sample has a smaller or greater variance than the other sample, and for $t$ test, one sample has a smaller or greater mean than the other.

We illustrate this methodology for three elements ( $\mathrm{Si}, \mathrm{Ti}$, and Al; Table 13- Appendix A - Supplementary material) as examples.

For Si (\%), $\mathrm{F}_{\text {calc }}=5.64635769$ was compared with the critical value (two-sided 99\% confidence level, 99\%ts; where ts means two-sided or two-tailed) for $v_{1}=6$ and $v_{2}=143$ (obtained from interpolation of critical values in Table 3) $\mathrm{cv}_{99 \% \mathrm{ts},(\mathrm{vl}=6, v 2=143)}=3.25498$. Because $\mathrm{F}_{\text {calc }}>$ $\mathrm{cv}_{99 \% \mathrm{ts},(v 1=6, v 2=143)}$, we concluded that $\mathrm{H}_{0}$ is false (F), i.e., all method groups for $\mathrm{Si}(\%)$ did not come from a single population, i.e., some sample(s) originated from a population having different mean or variance, or both.

Another case would be $\mathrm{Ti}(\%)$, for which $\mathrm{F}_{\text {calc }}$ $(3.1966244)<\mathrm{cv}_{99 \% \mathrm{ts},(\mathrm{vl}=6, \mathrm{v2}=162)}=3.234068$, corresponding to $v 1=6, v 2=162$, making $\mathrm{H}_{0}$ to be true $(\mathrm{T})$, and we would conclude that all method groups were drawn from the same population. Note this inference is different from that for $\mathrm{Si}(\%)$.

The third example is for $\mathrm{Al}(\%)$, with $\mathrm{F}_{\text {calc }}$ (1.8238030) $<\mathrm{cv}_{99 \% \mathrm{ts},(v 1=6, v 2=150)}(3.24457$ from Table 3), corresponding to $v 1=6, v 2=150$ ), making $H_{0}$ to be true $(\mathrm{T})$, and we would conclude that all method groups were drawn from the same population. Note that this example does not require the use of interpolation equations, because the critical value can be found in Table ES11 (available from any of the authors).

Thus, for 45 elements $\mathrm{H}_{0}$ is true (identified by T-truein the last column of Table 13), i.e., data from different method groups can be combined to process them further.
However, because significant differences were inferred in the data from different method groups for 11 elements (identified by $\mathrm{F}$-false- in the last column of Table 13; see also Table 14, Appendix A - Supplementary material), the results of only those method groups that do not show significant differences among them, can be combined (Table 14). For example (see Table 14), for $\mathrm{Si}(\%)$, the data from all method groups (Gr1, Gr2, Gr3, Gr4, Gr5, and Gr8), except Gr6, can be combined to calculate the central tendency and dispersion parameters.

Nevertheless, because the significance tests (ANOVA, $\mathrm{F}$ and $\mathrm{t})$ require that the data in individual samples be normally distributed, all samples were first processed by DODESSYS and after that the ANOVA test was applied to discordant-outlier-free data (Tables 15 and 16, Appendix A - Supplementary material). Twenty elements (when ANOVA was applied after the use of DODESSYS) instead of eleven (when ANOVA was applied without the use of DODESSYS) showed significant differences among method groups (compare Tables 15 and 16 with Tables 13 and 14, respectively). This implies that the application of ANOVA does depend on the presence of outlying observations, and it is recommended to assure that the samples under evaluation are free from such data. Further, it appears that for most elements the mass spectrometry methods (Gr6) provided results different from the other methods (Table 16).

\subsubsection{Comparison of the ANOVA with F-t tests and the two standard deviation method (2s) for $G-2$}

After the application of DODESSYS and ANOVA as explained above, the combined geochemical data for G-2 from those analytical methods that showed no significant differences, were processed once again in DODESSYS (using multiple-outlier tests at $99 \%$ confidence level) to separate any other discordant outliers and obtain the final statistics (see the three columns marked ANOVA test in Table 17, Appendix A - Supplementary material). Note that the identify of the geochemical data from the analytical method or methods that showed significant differences from the remaining methods was maintained, and their statistics were presented separately in Table 17, for example, note $\mathrm{Ti}(\%)$ is listed two times in Table 17. Thus, for seven cases (Ti (\%), Ca (\%), Na (\%), La, Sm, Sc and Th; Table 17), the ANOVA test had shown that the data from one method group (e.g., Gr3, x-ray fluorescence spectrometry for Ti) should not be combined with the other methods.

These results were compared with those reported by Verma and Cruz-Huicochea (2013) from the test and by Gladney et al. (1992) from the 2 s method. We note that the comparison of the ANOVA, F-t, and 2s methods 


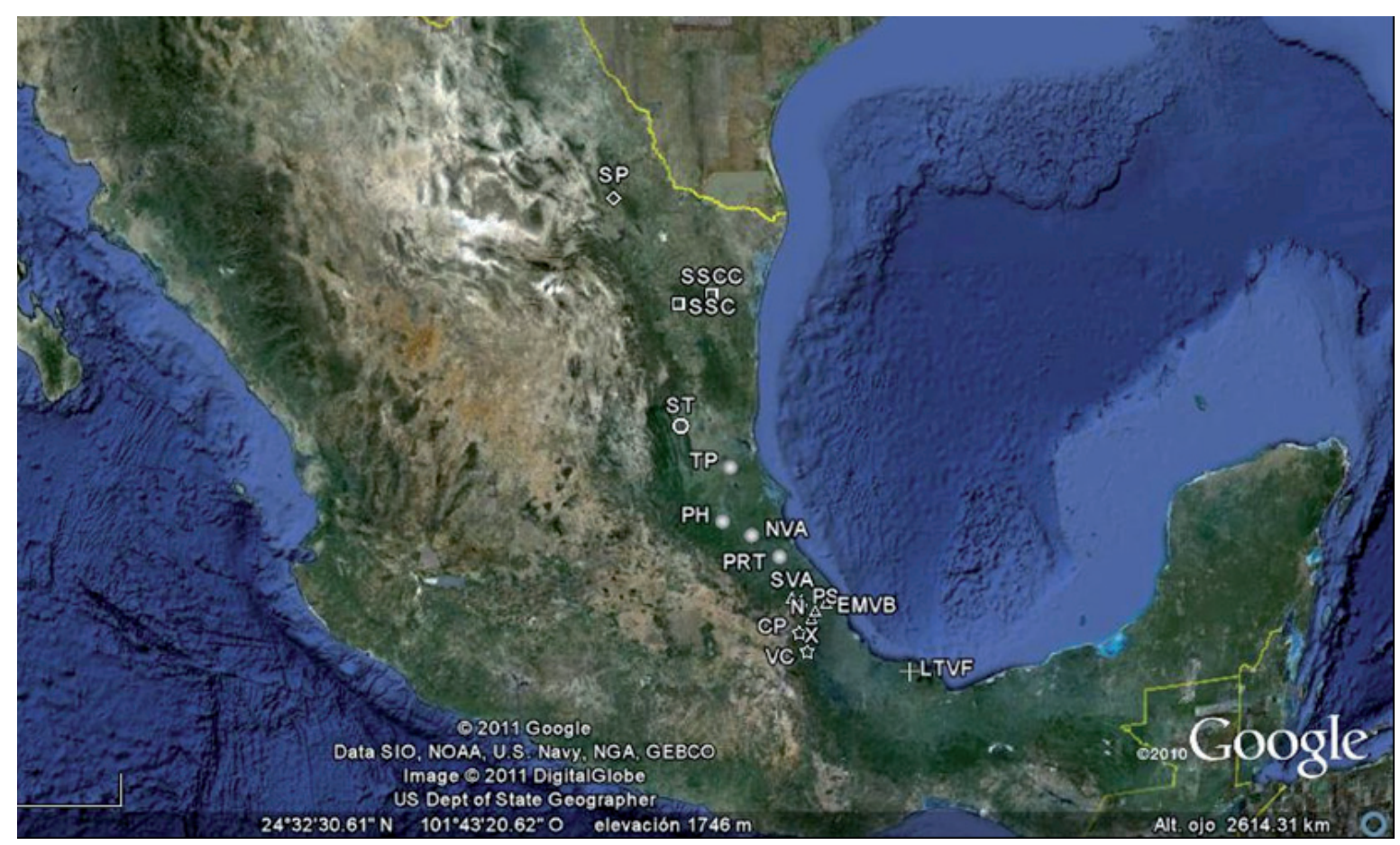

Fig. 1.- Schematic location of the Eastern Alkaline Province (EAP) in Mexico and U.S.A. (modified after 2011 Google Earth and Europa Tecnologies). The abbreviations are as follows: Region 1 (Rg1: AM-Alamo Mountains; CD-Cerro del Diablo; MP-El Muerto peak; CMCornuda Mountains); Region 2 (Rg2: SP-Sierra Pichaco); Region 3 (Rg3: SSC-Sierra San Carlos; SSCC-Sierra San Carlos-Cruillas); Region 4 (Rg4: ST-Sierra Tamaulipas); Region 5 (Rg5: NVA-Northern volcanic area; PH-Pachuca-Huejutla; PRT-Poza Rica-Tantimo; TP-Tampico plain; also designated as consisting of Hidalgo and northern Veracruz states); Region 6 (Rg6: SVA-Southern volcanic area; N-Naolinco; EMVB-Eastern Mexican Volcanic Belt; PS-Palma Sola; X-Xalapa; also designated as consisting of central Veracruz state); Region 7 (Rg7: VC-Volcán Citláltepetl; CP-Cofre de Perote); and Region 8 (Rg8: LTVF-Los Tuxtlas volcanic field).

Fig. 1.- Localización esquemática de la Provincia Alcalina Oriental en México y E.U.A. (datos de localización tomados de 2011 Google Earth and Europa Tecnologies). La abreviaturas son las siguientes: Región 1 (Rg1: AM-Montañas de Alamo; CD-Cerro del Diablo; MPEl pico del Muerto; CM-Montañas Cornuda); Región 2 (Rg2: SP-Sierra Pichaco); Región 3 (Rg3: SSC-Sierra San Carlos; SSCC-Sierra San Carlos-Cruillas); Región 4 (Rg4: ST-Sierra Tamaulipas); Región 5 (Rg5: NVA-Área volcánica del norte; PH-Pachuca-Huejutla; PRT-Poza Rica-Tantimo; TP-plano de Tampico; también se le designó como el estado de Hidalgo y la parte norte de Veracruz); Región 6 (Rg6: SVA- Área volcánica del sur; N-Naolinco; EMVB- parte este del Cinturón Volcánico Mexicano; PS-Palma Sola; X-Xalapa; también se le designó como la parte central del estado Veracruz); Región 7 (Rg7: VC-Volcán Citláltepetl; CP-Cofre de Perote); Región 8 (Rg8: LTVF-el campo volcánico de Los Tuxtlas).

should, however, be better or more objectively performed if the ANOVA and F-t tests were applied at a less strict $95 \%$ confidence level.

Although we have not applied significance tests for this comparison, the mean values obtained from ANOVA showed some differences from the F-t tests for 42 cases and from the literature for 57 cases (Table 17). Out of 60 major and trace elements (Table 17), the standard deviation values obtained from the ANOVA test were lower than the F-t tests for 37 elements, equal for 10 elements, and higher for the remaining 13 elements. Similarly, the standard deviation values from ANOVA were lower than the literature data ( $2 \mathrm{~s}$ method) for 28 elements, equal for 2 elements, and higher for 30 elements. Such differences in the mean and standard deviation values, irrespective of whether statistically significant or not, may affect the calibration of instruments or the evaluation of analytical methods (e.g., Santoyo and Verma, 2003; Guevara et al.,
2005; Verma et al., 2009; Verma, 2012a).

Although as done in our companion paper (Verma and Cruz-Huicochea, 2013) we have presented only one example (granite G-2), this kind of application will be useful for evaluating geochemical data for all other rock reference materials (e.g., Gladney and Roelandt, 1988; Imai et al., 1995; Verma, 1997, 1998; Velasco-Tapia et al., 2001; Marroquín-Guerrra et al., 2009; Pandarinath, 2009a) or water reference materials (e.g., M.P. Verma, 2013).

\subsection{Evaluation of geochemical data from the Eastern Alkaline Province (EAP) of Mexico and U.S.A.}

We compiled data for 575 rock samples of all igneous rock types from eight regions in the Eastern Alkaline Province (EAP; Rg1 to Rg8; see Figure 1 for more details on regions). The region numbering is arranged approximately from north to south as follows: (1) Rg1-U.S.A.; 
Rg2-Sierra Picacho (Nuevo León); Rg3-Sierra San Carlos (Tamaulipas); Rg4-Sierra Tamaulipas (Tamaulipas); Rg5-various locations in the Hidalgo and Veracruz states; Rg6-various locations in the Veracruz state; Rg7two volcanic regions in the Veracruz state; and Rg8-Los Tuxtlas (Veracruz). The magma and rock types were automatically determined from the computer program SINCLAS (Verma et al., 2002).

The literature sources were as follows: Robin (1976), Robin and Tournon (1978), Demant (1981), Kudo et al. (1985), Negendank et al. (1985), Nick (1988), Morton Bermea (1990), Elías-Herrera et al. (1991), Nelson and Gonzalez-Caver (1992), Verma et al. (1993), Nelson et al. (1995), Orozco-Esquivel (1995), McLemore et al. (1996), Potter (1996), Ramírez-Fernández (1996), Carrasco-Núñez (2000), Siebert and Carrasco-Núñez (2002), Gómez-Tuena et al. (2003), Treviño-Cázares et al. (2005), Rossotti et al. (2006), Verma (2006), OrozcoEsquivel et al. (2007), Espíndola et al. (2010), and Rodríguez et al. (2010).

For comparing compositional data, although it is not customary to apply the ANOVA test, this test for three or more statistical samples or the F-t combination for two statistical samples should always be applied for statistically correct comparisons. However, ANOVA requires that the data for each region be normally distributed (Jensen et al., 1997; Verma, 2005). Therefore, in order to evaluate the effects of the fulfillment of this condition of normal distribution, we compared the data from these eight regions both before and after the application of DODESSYS (Verma and Díaz-González, 2012), which helps identify possible discordant outliers for each parameter. The results of application of ANOVA are summarised in Tables 18-23 for ultrabasic, basic, and intermediate magmas (Appendix A - Supplementary material). The symbols used in these tables are presented in Table 24 (Appendix A - Supplementary material).

After the application of DODESSYS, the statistics of compositional data (number of samples, mean, and standard deviation) from each region are summarized in Tables 25, 26, and 27 for ultrabasic, basic, and intermediate rocks, respectively (Appendix A - Supplementary material). If we were interested to know the average compositions of this entire area (Eastern Alkaline Province of Mexico and U.S.A.), the results of ANOVA will have to be taken into account (Tables 19, 21, and 23, respectively) to combine the regions with no significant differences for a given parameter. This has not been specifically done in this work; we have simply summarized the statistical data individually for each region.

\subsubsection{Ultrabasic rocks}

Ultrabasic rocks are present in five of the eight regions compiled in this study. The ANOVA test was applied to these data to determine if these rocks showed statistically significant differences (Table 18). When DODESSYS was applied to these data before ANOVA, the results are summarized in Table 19. The statistics of compositions of these ultrabasic rocks are presented in Table 20.

For the major element $\left(\mathrm{SiO}_{2}\right)_{\text {adj }}$, ANOVA did not identify any three regions (out of five) that have similar concentrations. Therefore, all five regions are listed in the last column of Table 18. On the other hand, for two major elements $\left(\mathrm{Al}_{2} \mathrm{O}_{3}\right)_{\text {adj }}$ and $(\mathrm{MnO})_{\text {adj }}$ all regions could be grouped together because none of them showed significant differences. For other seven major elements (adjusted $\mathrm{TiO}_{2}, \mathrm{Fe}_{2} \mathrm{O}_{3}{ }^{\mathrm{t}}, \mathrm{MgO}, \mathrm{CaO}, \mathrm{Na}_{2} \mathrm{O}, \mathrm{K}_{2} \mathrm{O}$ and $\mathrm{P}_{2} \mathrm{O}_{5}$; Table 18) one or two regions showed significant differences with respect to the remaining regions. For example, for $\left(\mathrm{TiO}_{2}\right)_{\mathrm{adj}}$ two regions (Rg4 and $\left.\mathrm{Rg} 8\right)$ showed significantly different concentrations as compared to the remaining three regions (Rg3, Rg5, and $\mathrm{Rg} 6$ ). For two parameters (salic and femic minerals) based on major elements, all regions could be grouped together, because no region showed significant differences. For other such parameters, one or two regions showed differences with respect to the remaining ones.

One trace element $(\mathrm{Sc})$ showed significant differences among the three regions under study. For seventeen trace elements (Pr, Dy, Ho, Er, Tm, Lu, Co, Cs, Cu, Ga, Pb, Sr, Th, U, V, Y, and Zn), none of the regions showed significant difference. For the remaining trace elements (Table 18 ) at least three regions did not show any significant difference.

Thirteen ratio parameters, such as (LREE4) $)_{\mathrm{NOE}}$ and $(\text { HREE3) })_{\mathrm{NOE} 1}$, were statistically similar for all regions listed in Table 18 (for the explanation of these parameters, see Table 24 in Appendix A - Supplementary material). For most other parameters, one region ( $\mathrm{Rg} 4)$ showed significant differences as compared to the remaining regions (Table 18).

The application of DODESSYS showed that for $\left(\mathrm{Na}_{2} \mathrm{O}\right)$ ad, in addition to Rg3 (Table 6), Rg4 also showed significant differences in comparison with the remaining regions (Table 19). Similarly, total iron values expressed as $\left(\mathrm{Fe}_{2} \mathrm{O}_{3}{ }^{t}\right)_{\text {adj }}$ for only one region ( $\left.\mathrm{Rg} 8\right)$ were different from the other regions (Table 18), but the prior application of DODESSYS rendered that for this parameter two regions (Rg6 and Rg8) were different from the remaining regions (Table 19). The results for all other major-elements remained unchanged. 
Two trace elements ( $\mathrm{Rb}$ and $\mathrm{Zn}$ ) showed additional significant differences for one more region ( $\mathrm{Rg} 3$ and $\mathrm{Rg} 4$, respectively). For Sc, significant differences were observed in all groups. Solidification index (S.I.) showed significant difference for only one region $(\mathrm{Rg} 4)$. Finally, five ratio parameters $-(\text { LILE4 })_{\mathrm{NOE} 1}$, (LILE3 $)_{\mathrm{NOE} 2}$, (LILE3) ${ }_{\mathrm{NOE} 3}$, $\mathrm{Ba} / \mathrm{Nb}$, and $\mathrm{Nb} / \mathrm{Nb}^{*}$ - also showed differences for one or more additional region- $\mathrm{Rg} 3, \mathrm{Rg} 3, \mathrm{Rg} 3, \mathrm{Rg} 4$, and Rg4$\operatorname{Rg} 5$, respectively. Note that some chemical parameters, such as $\left(\mathrm{K}_{2} \mathrm{O}\right)_{\text {adj }}$ in $\mathrm{Rg} 3$ or $\left(\mathrm{P}_{2} \mathrm{O}_{5}\right)_{\text {adj }}$ in $\mathrm{Rg} 8$, are represented by a lesser number of samples (Table 25), because a few data were identified by DODESSYS as discordant. For some trace elements in some regions, for example, REE (La to Lu) in Rg3, the data are absent because these samples were not analyzed for these elements by the original authors.

Further, as is customary in geochemical studies, not all samples analyzed for major elements were studied for trace elements, being the reason that the number of samples for trace elements is equal or smaller than that for major elements.

Table 25 (Appendix A - Supplementary material) presents the statistical synthesis for all major elements, 12 lanthanides and 20 other trace elements in ultrabasic rock samples for only five regions, because only for them information was available in our database.

It is important to note that the number of samples listed along with the central tendency (mean) and dispersion (standard deviation) parameters can, in future, be statistically evaluated, for example, estimation of total uncertainty or comparison with other geological areas involving significance tests (ANOVA or F-t). Student $t$ values would be required for the estimation of total uncertainty (Verma and Cruz-Huicochea, 2013). Therefore, we stress that in all studies, the statistical synthesis should consist of at least these three statistical parameters (n, mean, and standard deviation; Table 25); a fuller statistical report would present the total uncertainty as the upper and lower confidence limits of the mean.

\subsubsection{Basic rocks}

Basic rocks are present in six of the eight regions compiled in this study. The ANOVA test was applied to these data to determine if these rocks showed statistically significant differences (Table 20). When DODESSYS was applied to these data before ANOVA, the results are summarised in Table 21. The statistics of compositions of these basic rocks are presented in Table 20.

For $(\mathrm{MnO})_{\text {adj }}$ all regions could be grouped together because ANOVA did not identify any significant difference for this parameter. For other nine major elements (adjusted $\mathrm{SiO}_{2}, \mathrm{TiO}_{2}, \mathrm{Al}_{2} \mathrm{O}_{3}, \mathrm{Fe}_{2} \mathrm{O}_{3}{ }^{\mathrm{t}}, \mathrm{MgO}, \mathrm{CaO}, \mathrm{Na}_{2} \mathrm{O}, \mathrm{K}_{2} \mathrm{O}$ and
$\mathrm{P}_{2} \mathrm{O}_{5}$; Table 20) one, two, or even three regions showed significant differences with respect to the remaining regions (Table 20). For example, for $\left(\mathrm{SiO}_{2}\right)_{\text {adj }}$ two regions (Rg8 and Rg6) showed significantly different concentrations as compared to the remaining four regions (Rg2, $\mathrm{Rg} 3, \operatorname{Rg} 4$, and $\operatorname{Rg} 5$ ). For all parameters based on major elements, one, two or three regions showed differences with respect to the remaining ones. For example, $\mathrm{Mg} \#$ values for $\operatorname{Rg} 8, \operatorname{Rg} 3$ and $\operatorname{Rg} 6$ were different from $\operatorname{Rg} 2$, Rg4, and Rg5 (Table 20).

One trace element $(\mathrm{V})$ showed significant differences among all four regions for which data were available. For ten trace elements $(\mathrm{Ce}, \mathrm{Pr}, \mathrm{Nd}, \mathrm{Sm}, \mathrm{Eu}, \mathrm{Gd}, \mathrm{Er}, \mathrm{Tm}, \mathrm{Ga}$, and $\mathrm{Zn}$ ), none of the regions showed significant differences. For the remaining trace elements (Table 20), at least three regions did not show any significant differences.

Three ratio parameters, (LREE4) $)_{\mathrm{NOE}}$, (LREE3) $)_{\mathrm{NOE} 1}$ and LILE4/LREE4, were statistically similar for all regions listed in Table 20. For other parameters, one, two, or three regions showed significant differences as compared to the remaining regions (Table 20).

The application of DODESSYS showed significant differences for $(\mathrm{MnO})_{\text {adj }}$ from one region $(\mathrm{Rg} 6)$ in comparison with the remaining regions (Table 21); note that if DODESSYS was not applied before ANOVA, no differences existed (Table 20). For $\left(\mathrm{K}_{2} \mathrm{O}\right)_{\text {adj }}$, in addition to $\mathrm{Rg} 2$ and Rg8 (Table 20), Rg3 also showed significant differences in comparison with the remaining regions (Table 21). The application of DODESSYS prior to ANOVA also resulted in different results for $(\mathrm{MgO})_{\text {adj }}\left(\mathrm{Na}_{2} \mathrm{O}\right)_{\text {adj }}$ and $\left(\mathrm{P}_{2} \mathrm{O}_{5}\right)_{\text {adj }}$ as well as for $\mathrm{T}_{\text {alk }}, \mathrm{FeO}^{\mathrm{t}} / \mathrm{Mg}$, Salic, Femic and A.R. (compare Tables 20 and 21). For C.I., significant differences were observed in all groups.

As a result of DODESSYS, seven trace elements (Ho, $\mathrm{Er}, \mathrm{Ba}, \mathrm{Cu}, \mathrm{Nb}, \mathrm{Rb}$ and $\mathrm{Th}$ ) showed additional significant differences for one more region (Table 21). In four trace elements ( $\mathrm{Lu}, \mathrm{Cs}, \mathrm{Hf}$, and $\mathrm{Pb}$ ), the results showed different regions with significant differences in comparison with the previous results (compare Tables 20 and 21). For $\mathrm{V}$, significant differences were observed for all groups. Finally, for one ratio parameter, significant differences were observed for all groups and the other eight ratio parameters, also showed differences for one or more additional regions (compare Tables 20 and 21). For ten parameters, the results (Table 21) showed different regions with significant differences in comparison with the previous results (Table 20).

Table 26 (Appendix A - Supplementary material) presents statistical parameters for basic rocks from the individual regions of the EAP in the same way as done for ultrabasic rocks (Table 25), and all earlier comments for the subsection of ultrabasic rocks are valid for basic rocks. 



Fig. 2.- Application of the set of five discriminant function multi-dimensional tectonic diagrams based on major-elements (Verma et al., 2006) to basic and ultrabasic rocks from the different regions of the Eastern Alkaline Province (EAP) of Mexico. The symbols used for the different regions of the EAP (for more details see Figure 1) are explained as inset in Figure 2 (a); filled symbols are used for discordant outliers as inferred from DODESSYS (Verma and Díaz-González, 2012). The names of x-y axes in the different diagrams explicitly show the tectonic field discriminated in that particular diagram and the subscript $\mathrm{m} 2$ stands for the second set of such multi-dimensional diagrams based on major elements. (a) Four-field diagram IAB-CRB-OIB-MORB; (b) Three-field diagram IAB-CRB-OIB; (c) Three-field diagram IAB-CRBMORB; (d) Three-field diagram IAB-OIB-MORB; and (e) Three-field diagram CRB-OIB-MORB. The abbreviations used are as follows: IAB-island arc basic (and ultrabasic) rocks; CRB-continental rift basic (and ultrabasic) rocks; OIB-ocean island basic (and ultrabasic) rocks; and MORB-mid-ocean ridge basic (and ultrabasic) rocks.

Fig. 2.- Aplicación del conjunto de cinco diagramas multi-dimensionales tipo funciones discriminantes basados en elementos mayores (Verma et al., 2006) a rocas básicas y ultrabásicas de las diferentes regiones de la Provincia Alcalina Oriental de México. Se explican los símbolos usados par a las diferentes regiones de esta provincia (para mayores detalles ver la Figura 1) dentro de la Figura 2 (a); se usan los símbolos rellenos para valores extremos discordantes como ha sido inferido por DODESSYS (Verma y Díaz-González, 2012). Los nombres de los ejes $\mathrm{x}-\mathrm{y}$ en los diferentes diagramas contienen los campos tectónicos discriminados en ese diagrama en particular y el suscrito m2 significa que se trata del segundo conjunto de diagramas multi-dimensionales basados en elementos mayores. (a) Diagrama de cuatro campos IAB-CRB-OIBMORB; (b) Diagrama de tres campos IAB-CRB-OIB; (c) Diagrama de tres campos IAB-CRB-MORB; (d) Diagrama de tres campos IABOIB-MORB; y (e) Diagrama de tres campos CRB-OIB-MORB. Las abreviaturas usadas son las siguientes: IAB-rocas básicas (y ultrabásicas) de arco de isla; CRB-rocas básicas (y ultrabásicas) de rift continental; OIB-rocas básicas (y ultrabásicas) de islas oceánicas; y MORB-rocas básicas (y ultrabásicas) de crestas mid-oceánicas.

\subsubsection{Intermediate rocks}

Intermediate rocks are present in all regions compiled in this study. In order to determine if these rocks showed statistically significant differences, the ANOVA test was applied to these data (Table 22). When DODESSYS was applied to these data before ANOVA, the results are summarized in Table 23. The statistics of compositional data for these intermediate rocks are presented in Table 27 (Appendix A - Supplementary material).
For major elements, in all cases (adjusted $\mathrm{SiO}_{2}, \mathrm{TiO}_{2}$, $\mathrm{Fe}_{2} \mathrm{O}_{3}{ }^{\mathrm{t}}, \mathrm{Al}_{2} \mathrm{O}_{3}, \mathrm{MnO}, \mathrm{MgO}, \mathrm{CaO}, \mathrm{Na}_{2} \mathrm{O}, \mathrm{K}_{2} \mathrm{O}$ and $\mathrm{P}_{2} \mathrm{O}_{5}$; Table 22) ANOVA identified one or more regions that showed significant differences with respect to the remaining regions. For all parameters based on major elements, at least one or more regions showed differences with respect to the remaining regions.

For six trace elements (Sm, Tb, Ho, Tm, Co and U), none of the regions showed significant differences. For the remaining trace elements (Table 22) one or more re- 

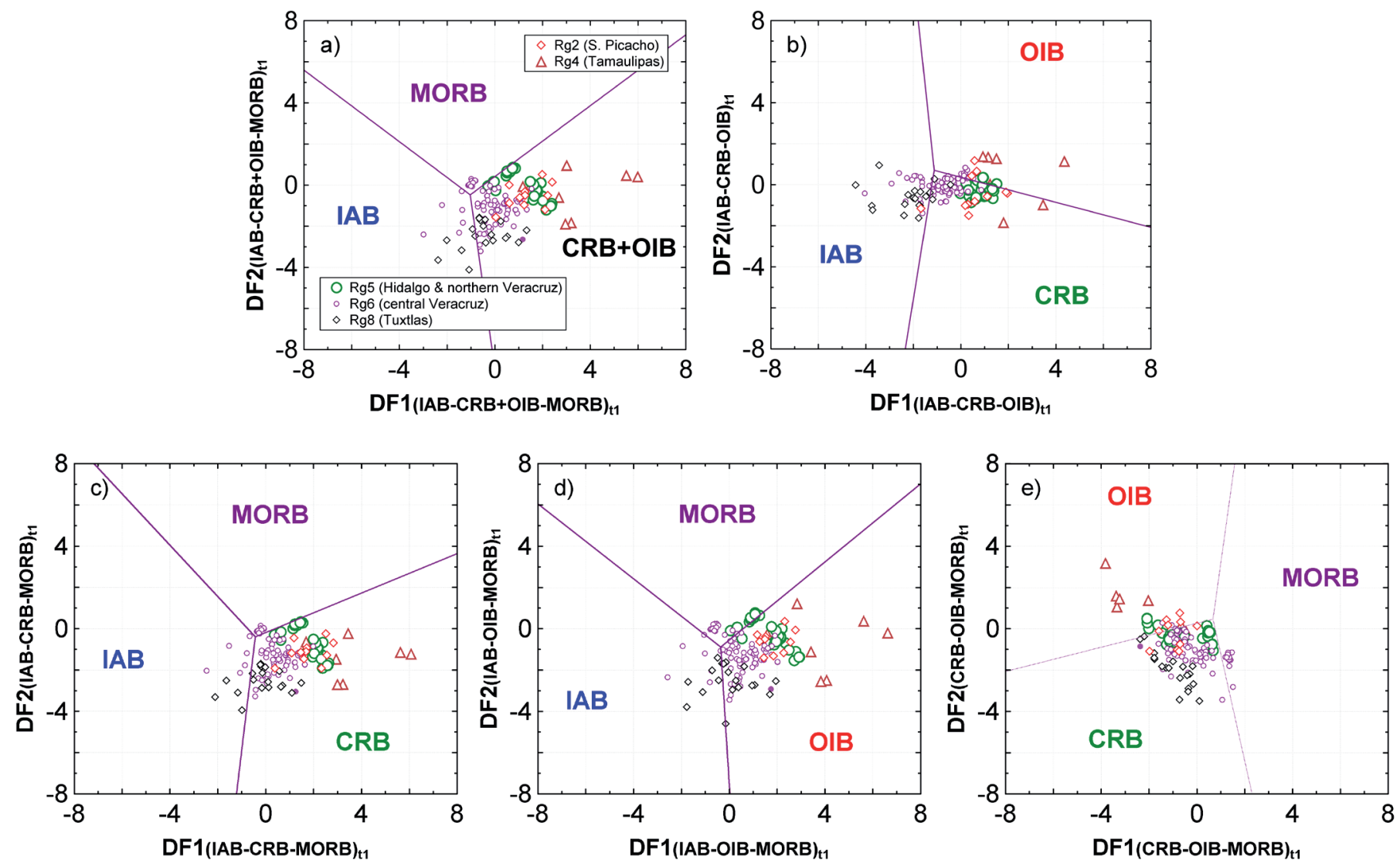

Fig. 3.- Application of the set of five discriminant function multi-dimensional tectonic diagrams based on trace elements (Agrawal et al., 2008) to basic and ultrabasic rocks from the different regions of the Eastern Alkaline Province (EAP) of Mexico. The symbols used for the different regions of the EAP (for more details see Figure 1) are explained as inset in Figure 3 (a); filled symbols are used for discordant outliers as inferred from DODESSYS (Verma and Díaz-González, 2012). The names of x-y axes in the different diagrams explicitly show the tectonic field discriminated in that particular diagram and the subscript t1 stands for the first set of such multi-dimensional diagrams based on trace elements. (a) Three-field diagram IAB-CRB+OIB-MORB where CRB and OIB fields are clubbed together; (b) Three-field diagram IABCRB-OIB; (c) Three-field diagram IAB-CRB-MORB; (d) Three-field diagram IAB-OIB-MORB; and (e) Three-field diagram CRB-OIBMORB. The abbreviations used are as follows: IAB-island arc basic (and ultrabasic) rocks; CRB-continental rift basic (and ultrabasic) rocks; OIB-ocean island basic (and ultrabasic) rocks; and MORB-mid-ocean ridge basic (and ultrabasic) rocks.

Fig. 3.- Aplicación del conjunto de cinco diagramas multi-dimensionales tipo funciones discriminantes basados en elementos mayores (Agrawal et al., 2008) a rocas básicas y ultrabásicas de las diferentes regiones de la Provincia Alcalina Oriental de México. Se explican los símbolos usados par alas diferentes regiones de esta provincia (para mayores detalles ver la Figura 1) dentro de la Figura 3 (a); se usan los símbolos rellenos para valores extremos discordantes como ha sido inferido por DODESSYS (Verma y Díaz-González, 2012). Los nombres de los ejes $\mathrm{x}-\mathrm{y}$ en los diferentes diagramas contienen los campos tectónicos discriminados en ese diagrama en particular y el suscrito t1 significa que se trata del primer conjunto de diagramas multi-dimensionales basados en elementos traza. (a) Diagrama de tres campos IAB-CRB+OIB-MORB donde los campos CRB y OIB se encuentran juntos; (b) Diagrama de tres campos IAB-CRB-OIB; (c) Diagrama de tres campos IAB-CRBMORB; (d) Diagrama de tres campos IAB-OIB-MORB; y (e) Diagrama de tres campos CRB-OIB-MORB. Las abreviaturas usadas son las siguientes: IAB-rocas básicas (y ultrabásicas) de arco de isla; CRB-rocas básicas (y ultrabásicas) de rift continental; OIB-rocas básicas (y ultrabásicas) de islas oceánicas; y MORB-rocas básicas (y ultrabásicas) de crestas mid-oceánicas.

gions showed significant differences compared to the remaining regions.

For ratio parameters, five (LILE5/HFSE6, LILE5/HFSE5a, LILE5/HSFE5b, LILE4/HFSE4b, and LREE3/ HFSE4a) were statistically similar for all regions listed in Table 22. For most other parameters at least three regions did not show any significant difference.

For three major elements (adjusted $\mathrm{SiO}_{2}, \mathrm{MnO}$ and $\mathrm{MgO})$, the application of DODESSYS showed different results than those obtained without DODESSYS (com- pare Tables 22 and 23). In the same way, $\mathrm{T}_{\mathrm{alk}}$, A.R. and salic parameters showed additional significant differences for one and two more regions $(\operatorname{Rg} 3, \operatorname{Rg} 3$ and $\operatorname{Rg} 3$, respectively). Six trace elements (La, Sm, Ho, Ga, U, and $\mathrm{Zn}$ ) showed additional significant differences for one or more regions. For three trace elements (Ba, $\mathrm{Cs}$ and $\mathrm{Sr}$ ), the results showed different regions with significant differences (Table 23) in comparison with the previous results (Table 22). Finally, six ratio parameters (LILE5/HFSE6, LILE5/ HFSE5a, LILE5/HFSE5b, LILE4/HFSE4a, LILE4/HF- 
SE4b, and LILE4/HFSE4c) also showed differences for one additional region $(\mathrm{Rg} 1)$ and for six parameters the results showed different regions with significant differences in comparison with the previous result (Table 22).

Table 27 presents the statistical parameters for intermediate rocks from the individual regions of the EAP, and the comments made in the subsection of ultrabasic rocks are also valid.

\section{Application of multi-dimensional discrimination diagrams}

New multi-dimensional discrimination diagrams have been recently proposed for tectonic discrimination of basic and ultrabasic magmas (Agrawal et al., 2004, 2008; Verma et al., 2006; Verma and Agrawal, 2011) and for acid magmas (S.K. Verma et al., 2012). New diagrams based on all major elements, selected immobile major and trace elements, and immobile trace elements have also recently put forth for intemediate magmas (Verma and Verma, 2013) and for acid magmas (Verma et al., 2013a), which can be used in future to better understand the tectonic setting and their relationship to magma compositions.

These multi-dimensional diagrams have been positively evaluated and used by the original authors as well as several workers (e.g., Rajesh, 2007; Sheth, 2008; Aparicio and García, 2009; Polat et al., 2009a, 2009b, 2011; Ramakrishnan, 2009; Verma, 2009, 2010, 2012b, 2013; Bailie et al., 2010, 2012; Slovenec et al., 2010; Wang et al., 2010; Zhang et al., 2010; Pandarinath and Verma, 2013; Verma and Verma, 2013). Importantly, the proposal of these newer diagrams (Verma et al., 2006; Agrawal et al., 2008; Verma and Agrawal, 2011) and their use fully complies with the statistical requirements for handling compositional data (Aitchison, 1986; Agrawal and Verma, 2007; Verma, 2012a). Computer program TecD (Verma and Rivera-Gómez, 2013) greatly facilitates the use of these diagrams. More significantly, the log-transformed ratio variables and not the crude compositions should be processed by DODESSYS to identify discordant outliers (Verma and Díaz-González, 2012), as also suggested by Verma (2012a).

\subsection{Application of ANOVA and DODESSYS to log-transformed ratios}

As a statistically coherent procedure, we computed natural logarithm of element ratios and compared the transformed compositional data for ultrabasic and basic rocks (taken together) from different regions of the EAP (Tables 28, Appendix A - Supplementary material). The combined ultrabasic and basic rock data from a given area are required because the new diagrams are meant to be used for both types of magma. The first set of log-transformed ratios (Table 28) are used in the discrimination diagrams of Verma et al. (2006) for ultrabasic and basic rocks, whereas the other two sets are employed in the diagrams by Agrawal et al. (2008) and Verma and Agrawal (2011), respectively, both of which also proposed for ultrabasic and basic rocks. Then, we applied the ANOVA test to statistically compare these parameters at the strict 99\% confidence level. Even in the log-transformed ratios, significant differences exist among the regions of EAP under study. For example, for $\ln \left[\left(\mathrm{TiO}_{2}\right)_{\mathrm{adj}} /\left(\mathrm{SiO}_{2}\right)_{\mathrm{adj}}\right]$, two regions ( $\mathrm{Rg} 6$ and $\mathrm{Rg} 8$ ) are different from the remaining five regions (Table 28).

After the application of DODESSYS and separating the discordant outliers from the main data, ANOVA provided the comparisons summarized in Table 29 (Appendix A - Supplementary material). Although the conclusions of ANOVA about most ratio parameters remained practically the same as without the prior application of DODESSYS, they were different for two parameters (compare Tables 28 and 29), which are the following: (i) for In $\left[\left(\mathrm{Al}_{2} \mathrm{O}_{3}\right)_{\text {adj }} /\left(\mathrm{SiO}_{2}\right)_{\text {adj }}\right]$ two regions $(\mathrm{Rg} 2$ and $\mathrm{Rg} 8)$ were different from the other regions without the application of DODESSYS, but with this prior application, ANOVA showed that only one region $(\operatorname{Rg} 8)$ is different from the remaining regions; and (ii) for $\ln \left[\left(\mathrm{K}_{2} \mathrm{O}\right)_{\text {adj }} /\left(\mathrm{SiO}_{2}\right)_{\text {adj }}\right]$ two regions ( $\operatorname{Rg} 3$ and $\operatorname{Rg} 4)$ were different from the other regions without the application of DODESSYS, but with this application, ANOVA showed that three regions ( $\mathrm{Rg} 3$, $\mathrm{Rg} 4$, and $\mathrm{Rg} 5$ ) are different from the other regions.

\subsection{Application of new multi-dimensional discrimination diagrams for tectonic inferences}

These diagrams therefore can be used for inferring the tectonic setting of this area. We plotted the samples from our study in Figure 2 - the set of five diagrams based on log-transformed ratios of major elements (Verma et al., 2006) and in Figure 3 - the set of five diagrams based on log-transformed ratios of immobile trace elements (Agrawal et al., 2008). The results of application of these diagrams are summarized in Tables 30 and 31, respectively (Appendix A - Supplementary material).

Finally, instead of plotting the samples in the set of five diagrams (Verma and Agrawal, 2011), we decided to compute probabilities for individual samples as suggested by these authors. Note that in a given diagram, a particular sample will plot in the field for which the probability is the highest. Therefore, it is unnecessary to plot the samples in diagrams, and it is better to identify 
for any given sample the highest probability for a tectonic field. The samples along with their respective probabilities are summarized in Table 32 (Appendix A - Supplementary material).

As stated earlier, the log-transformed data used in the three sets of multi-dimensional diagrams (Verma et al., 2006; Agrawal et al., 2008; Verma and Agrawal, 2011), were also processed in DODESSYS (Verma and DíazGonzález, 2012), which separated the discordant outliers and rendered the bulk of data as discordant outlier-free. We also indicate the usefulness of this additional approach in the use of new discrimination diagrams.

We discuss first how these different diagrams are interpreted using the example of Rg2 (Sierra Picacho, Nuevo León, Tertiary rocks; Fig. 2a-e and Table 30). These diagrams can discriminate four tectonic settings of IAB (island arc basic rock; field or group no. 1), CRB (continental rift basic rocks; field or group no. 2), OIB (ocean island basic rocks; field or group no. 3), and MORB (midocean ridge basic rocks; field or group no. 4).

For the first diagram (1-2-3-4) of Verma et al. (2006) for basic and ultrabasic rocks, 14 out of 16 samples from $\mathrm{Rg} 2$ plot in the continental rift (CRB) field and the remaining two samples in the MORB field (Fig. 2a; see the first row of data in Table 30). Thus, a large proportion or percentage of these samples indicates a continental rift setting for Rg2.

The other diagrams (1-2-3, Fig. 2b; 1-2-4, Fig. 2c; 2-34, Fig. 2e; see also Table 30) also show that 14 of these 16 samples plot in the continental rift field. Given the consistency of these diagrams (Fig. 2a-c, e), the remaining diagram (1-3-4, Fig. 2d, in which the field no. 2 is absent) should be considered as the inapplicable diagram (see the asterisk mark after 1-3-4 in Rg2 of Table 30) for this case study. In such inapplicable diagrams, samples will plot in the tectonic field that has characteristics similar to the inferred tectonic setting from other diagrams; in this case, most $(10+1)$ samples plot in the ocean island field, which is very similar to the continental rift tectonic setting. Thus, the success rate for $\mathrm{Rg} 2$ discrimination as a continental rift is about $88 \%$ (14 out 16 samples).

It is interesting to note that the multiple-outlier type discordancy tests applied at the strict $99 \%$ confidence level identified two samples as having discordant data and incidentally both samples plotted in a field different from the continental rift, that is, they represent mis-discrimination (see solid diamond symbol in figure 2a-e and number enclosed in [] in Table 30). Thus, if we consider only the fourteen discordant outlier-free samples, the success rate for the continental rift setting would then be 100\% (14 out of 14 samples were correctly discriminated)!

The other regions ( $\operatorname{Rg} 4, \operatorname{Rg} 5, \operatorname{Rg} 6$, and $\operatorname{Rg} 8)$ were also discriminated as an extensional or a continental rift set- ting in these diagrams (Fig. 2 and Supplementary material: Table 30), whereas one region ( $\mathrm{Rg} 3$ ) likely indicated an ocean island setting. The discordant outliers for these regions were also a few in number and generally plotted in a tectonic field different from the inferred setting (Supplementary material: table 30 ).

The application of Agrawal et al. (2008) diagrams (Fig. 3a-e; Table 31, in Appendix A - Supplementary material) also indicated a continental rift setting for $\operatorname{Rg} 2, \operatorname{Rg} 5, \operatorname{Rg} 6$, and $\mathrm{Rg} 8$, whereas the remaining region $(\mathrm{Rg} 4)$ is likely an ocean island setting. No discordant outlier was observed for four regions ( $\operatorname{Rg} 2, \operatorname{Rg} 4, \operatorname{Rg} 5$, and $\operatorname{Rg} 8$ ), and only one discordant observation was present in $\operatorname{Rg} 6$ (Table 31).

The third set of diagrams (Verma and Agrawal, 2011; Table 32, in Appendix A - Supplementary material) indicated a continental rift setting for Rg3, transitional from continental rift to ocean island for $\mathrm{Rg} 4$, transitional from continental rift to MORB for Rg6, and inconclusive results for $\operatorname{Rg} 8$. No discordant outlier was observed for two regions ( $\mathrm{Rg} 3$ and $\mathrm{Rg} 4)$. One discordant observation was present in Rg6 and two in Rg8 (Table 32).

In summary, from all three sets of diagrams the results of an extensional or a continental rift setting for this area can be inferred, which is fully consistent with earlier conclusions by Verma (2006) for $\operatorname{Rg} 8$ and S.K. Verma et al. (2012) for Rg8 and some other regions of the EAP from a limited compilation of data.

\section{Additional considerations}

The ANOVA test is a powerful method to statistically decipher similarities and differences among three or more statistical samples drawn from normal populations. The computer program DODESSYS (Verma and DíazGonzález, 2012) is useful to identify and separate discordant outliers in such samples. This procedure should be applied prior to the ANOVA or F-t tests as well as for the use of new multi-dimensional tectonomagmatic diagrams. The $\mathrm{F}$ test has an additional application to know which version of the Student $t$ test should be applied to evaluate the mean values of two statistical samples drawn from normal populations. Sometimes, the $t$ test is applied probably without the prior explicitly stated application of the F test. For example, Wani and Mondal (2011), although presenting a rare example of statistical application in the geological literature, compared the compositions of calcareous and non-calcareous shales, through the $t$ test at $95 \%$ confidence level. We suggest that the $\mathrm{t}$ test should always be applied in combination with the F test, and preferably at the strict $99 \%$ confidence level. Furthermore, it is very important that prior to the application of ANOVA or F-t tests, DODESSYS (Verma and Díaz-González, 2012) should be advantageously used at 
the strict 99\% confidence level. Finally, instead of applying these statistical tests to crude compositional data as done in section 4 above, log-transformed ratios should be evaluated as done in section 5 (for more details, see Aitchison, 1986; Verma, 2012a).

Comparative studies, such as those reported by several workers (Balaram et al., 1995a, 1995b; Dai Kin et al., 1999; Tamisier-Korolak et al., 1999; Almeida et al., 2002; Kubala-Kukus et al., 2003; M.P. Verma, 2004, 2008; Bansal et al., 2008; and Kumar et al., 2008), can be correctly carried out by the use of the new critical values and the statistical procedures outlined in this work.

Finally, in future using the present new critical values for $\mathrm{F}$ and those for $\mathrm{t}$ (Verma and Cruz-Huicochea, 2013) numerous studies (e.g., Díaz-González et al., 2008; Armstrong-Altrin, 2009; Hernández-Martínez and Verma, 2009; Gómez-Arias et al., 2009; Madhavaraju and Lee, 2009; Marroquin-Guerra et al., 2009; Pandarinath, 2009a, 2009b; Álvarez del Castillo et al., 2010; Zeyrek et al., 2010; Torres-Alvarado et al., 2011), can be improved through the application of significance tests (ANOVA and F-t tests), provided the geochemometrics techniques (Verma, 2012a) are followed for handling compositional data.

\subsection{Relevant software for the application of discordancy and significance tests}

All critical values and equations were programmed in a new software UDASYS (Univariate Data Analysis SYStem), which is documented recently by Verma et al. (2013b). UDASYS facilitates the application of both categories of statistical methods for univariate data (robust and outlier-based; Verma, 2005), 33 discordancy tests (Verma and Díaz-González, 2012), and significance tests (Fisher's F, Student's t and ANOVA). All critical values simulated in this work and in the companion paper by Verma and Cruz-Huicochea (2013) and the relevant polynomial equations are programmed in UDASYS.

UDASYS helps apply the ANOVA, $F$ and $t$ tests more powerfully than the available commercial software systems. Anyone interested in using UDASYS for his or her work is invited to obtain it free of cost from any of the authors.

\section{Conclusions}

New precise and accurate critical values along with the corresponding standard error estimates as well as bestfit equations were developed for a better application of the ANOVA and F tests. Application examples have been presented to illustrate the statistically correct procedure for the comparison and evaluation of geochemical data. The geochemical data for ultrabasic and basic rock samples from the Eastern Alkaline Province of Mexico used in discriminant-function based multi-dimensional diagrams suggest an extensional or a continental rift setting for this volcanic province.

\section{Acknowledgements}

We are grateful to Alfredo Quiroz-Ruiz for help and guidance in the procurement and use of modern computing facilities. The Sistema Nacional de Investigadores (SNI-Conacyt) provided the necessary financial support for purchasing the special computing facilities and for assigning an assistantship to the first author $(\mathrm{RCH})$; both these actions enabled the development of the research work leading to this paper on application of critical values and other reports as well as for the culmination of Bachelor level thesis of RCH in Computer Engineering. We also thank the two reviewers Dr. V. Balaram and Dr. M. E. A. Mondal for kindly reading our manuscript; we are glad to see that both of them highly appreciated our work.

\section{References}

Agrawal, S., Verma, S.P. (2007): Comment on "Tectonic classification of basalts with classification trees" by Pieter Vermeesch (2006). Geochimica et Cosmochimica Acta 71, 3388-3390. doi:10.1016/j. gca.2007.03.036

Agrawal, S., Guevara, M., Verma, S.P. (2004): Discriminant analysis applied to establish major-element field boundaries for tectonic varieties of basic rocks. International Geology Review 46, 575-594. doi: 10.2747/0020-6814.46.7.575

Agrawal, S., Guevara, M., Verma, S.P. (2008): Tectonic discrimination of basic and ultrabasic rocks through log-transformed ratios of immobile trace elements. International Geology Review 50, $1057-$ 1079. doi: 10.2747/0020-6814.50.12.1057

Aitchison, J. (1986): The statistical analysis of compositional data. Chapman and Hall, London, New York: 416 p.

Almeida, C.M.R., Vasconcelos, M.T.S.D., Barbaste, M., Medina, B. (2002): ICP-MS multi-element analysis of wine samples - a comparative study of the methodologies used in two laboratories. Analytical and Bionalytical Chemistry 374, 314-322. doi: 10.1007/ s00216-002-1467-8

Álvarez del Castillo, A., Santoyo, E., García-Valladares, O., SánchezUpton, P. (2010): Evaluación estadística de correlaciones de fracción volumétrica de vapor para la modelación numérica de flujo bifásico en pozos geotérmicos. Revista Mexicana de Ingeniería Química 9, 285-311.

Aparicio, A., García, R. (2009): Basanites and crustal contamination in the Cartagena volcano field (South-East of Spain). ICFAI Journal of Earth Sciences 3, 23-40.

Armstrong-Altrin, J.S. (2009): Provenance of sands from Cazones, Acapulco, and Bahía Kino beaches, Mexico. Revista Mexicana de Ciencias Geológicas 26, 764-782.

Bailie, R., Gutzmer, J., Rajesh, H.M. (2010): Lithogeochemistry as a tracer of the tectonic setting, lateral integrity and mineralization of a highly metamorphosed Mesoproterozoic volcanic arc sequence on 
the eastern margin of the Namaqua Province, South Africa. Lithos 119, 345-362. doi: 10.1016/j.lithos.2010.07.012

Bailie, R., Rajesh, H.M., and Gutzmer, J. (2012): Bimodal volcanism at the western margin of the Kaapvaal Craton in the aftermath of collisional events during the Namaqua-Natal Orogeny: The Koras Group, South Africa. Precambrian Research 200, 163-183. doi:10.1016/j.precamres.2012.01.017.

Balaram, V., Anjaiah, K.V., Reddy, M.R.P. (1995a): Comparative study on the trace and rare earth element analysis of an Indian polymetallic nodule reference sample by inductively coupled plasma atomic emission spectrometry and inductively coupled plasma mass spectrometry. Analyst 120, 1401-1406. doi: 10.1039/AN9952001401

Balaram, V., Ramesh, S.L., Anjaiah, K.V. (1995b): Comparative study of the sample decomposition procedures in the determination of trace and rare earth elements in anorthosites and related rocks by ICP-MS. Fresenius' Journal of Analytical Chemistry 353, 176-182.

Bansal, V., Krishna, G.J., Singh, A.P., Gupta, A.K., Sarpal, A.S. (2008): Determination of hydrocarbons types and oxygenates in motor gasoline: A comparative study of different analytical techniques. Energy and Fuels 22, 410-415. doi: 10.1021/ef0701211

Barnett, V., Lewis, T. (1994): Outliers in statistical data. Third Edition, John Wiley \& Sons, Chichester: 584 p.

Bevington, P.R., Robinson, D.K. (2003): Data reduction and error analysis for the physical sciences. Third Edition. McGraw Hill, Boston: $320 \mathrm{p}$.

Carrasco-Núñez, G. (2000): Structure and proximal stratigraphy of Citlaltépetl volcano (Pico de Orizaba), Mexico. In: Cenozoic tectonics and volcanism of Mexico. Delgado-Granados, H., AguirreDíaz, G., Stock, J.M., Eds., Geological Society of America Special paper 334, 247-262. doi: 10.1130/0-8137-2334-5.247

Dai Kin, F., Prudêncio, M.I., Gouveia, A., Magnusson, E. (1999): Determination of rare elements in geological reference materials: a comparative study by INAA and ICP-MS. Geostandards Newsletter: The Journal of Geostandards and Geoanalysis 23, 47-58. doi: 10.1111/j.1751-908X.1999.tb00558.x

Demant, A. (1981): L'axe néo-volcanique transmexicain, étude volcanologique et pétrographique, signification géodynamique. Ph.D. thesis, 259 p., and appendix, Université de Droit, d'Economie et des Sciences d'Aix-Marseille.

Díaz-González, L., Santoyo, E., Reyes-Reyes, J. (2008): Tres nuevos geotermómetros mejorados de $\mathrm{Na} / \mathrm{K}$ usando herramientas computacionales y geoquimiométricas: aplicación a la predicción de temperaturas de sistemas geotérmicos. Revista Mexicana de Ciencias Geológicas 25, 465-482.

Ebdon, D. (1988): Statistics in Geography. Second Edition, Basic Blackwell, Oxford: 232 p.

Elías-Herrera, M., Rubinovich-Kogan, R., Lozano-Santa Cruz, R., Sánchez-Zavla, J.L. (1991): Nepheline-rich foidolites and rareearth mineralization in the El Picacho Tertiary intrusive complex, Sierra de Tamaulipas, northeastern Mexico. Canadian Mineralogist 29, 319-336.

Espíndola, J.M., Zamora-Camacho, A., Godinez, M.L., Schaaf, P., Rodríguez, S.R. (2010): The 1793 eruption of San Martín Tuxtla volcano, Veracruz, Mexico. Journal of Volcanology and Geothermal Research 197, 188-208. doi: 10.1016/j.jvolgeores.2009.08.005

Espinosa-Paredes, G., Verma, S.P., Vázquez-Rodríguez, A., NúñezCarrera, A. (2010): Mass flow rate sensitivity and uncertainty analysis in natural circulation boiling water reactor core from Monte Carlo simulations. Nuclear Engineering and Design 240, 1050-1062. doi: 10.1016/j.nucengdes.2010.01.012

Gladney, E.S., Roelandts, I. (1988): 1987 compilation of elemental concentration data for USGS BHVO-1, MAG-1, QLO-1, RGM-1, SCo-1, SDC-1, SGR-1, and STM-1. Geostandards Newsletter 12,
253-262.

Gladney, E.S., Jones, E.A., Nickell, E.J., Roelandts, I. (1992): 1988 compilation of elemental concentration data for USGS AGV-1, GSP-1 and G-2. Geostandards Newsletter 16, 111-300.

Gómez-Arias, E., Andaverde, J., Santoyo, E., Urquiza, G. (2009): Determinación de la viscosidad y su incertidumbre en fluidos de perforación usados en la construcción de pozos geotérmicos: aplicación en el campo de Los Humeros, Puebla, México. Revista Mexicana de Ciencias Geológicas 26, 516-529.

Gómez-Tuena, A., LaGatta, A.B., Langmuir, C.H., Goldstein, S.L., Ortega-Gutiérrez, F., Carrasco-Núñez, G. (2003): Temporal control of subduction magmatism in the eastern Trans-Mexican Volcanic Belt: mantle sources, slab contributions, and crustal contamination. Geochemistry Geophysics Geosystems 4, doi: 10.1029/2003GC000524.

González-Ramírez, R., Díaz-González, L., Verma, S.P. (2009): Eficiencia relativa de 15 pruebas de discordancia con 33 variantes aplicadas al procesamiento de datos geoquímicos. Revista Mexicana de Ciencias Geológicas 26, 501-515. doi: 10.1111/j.1751908X.2009.00885.x

Guevara, M., Verma, S.P., Velasco-Tapia, F., Lozano-Santa Cruz, R., Girón, P. (2005): Comparison of linear regression models for quantitative geochemical analysis: An example using x-ray fluorescence spectrometry. Geostandards and Geoanalytical Research 29, 271 284. doi: 10.1111/j.1751-908X.2005.tb00900.x

Hernández-Martínez, J.L., Verma, S.P. (2009): Reseña sobre las metodologías de campo, analíticas y estadísticas empleadas en la determinación y manejo de datos de los elementos de tierras raras en el sistema suelo-planta. Revista de la Facultad de Ciencias Agrarias Universidad Nacional de Cuyo 41, 153-189.

Imai, N., Terashima, S., Itoh, S., Ando, A. (1995): 1994 compilation of analytical data for minor and trace elements in seventeen GSJ geochemical reference samples, "igneous rock series". Geostandards Newsletter 19, 135-213. doi: 10.1111/j.1751-908X.1995.tb00158.x

Jennings, L.W., Young, D.M. (1988): Extended critical values of the multivariate extreme deviate test for detecting a single spurious observation. Communications in Statistics - Simulation and Computation 17, 1359-1373. doi: 10.1080/03610918808812729

Jensen, J.L., Lake, L.W., Corbett, P.W.M., Goggin, D.J. (1997): Statistics for petroleum engineers and geoscientists. Prentice-Hall, Upper Saddle River: 390 p.

Kanji, G.K. (1993): 100 Statistical Tests. SAGE Publications, London: $216 \mathrm{p}$.

Kubala-Kukus, A., Braziewicz, D.B.J., Majewska, U., Pajek, M. (2003): Comparative study of trace element contents in human fullterm placenta and fetal membranes by total reflection X-ray fluorescence. Spectrochimica Acta Part B 58, 725-734. doi: 10.1016/ S0584-8547(02)00285-9

Kudo, A.M., Jackson, M.E., Husler, J.W. (1985): Phase chemistry of recent andesite, dacite, and rhyodacite of volcan Pico de Orizaba, Mexican Volcanic Belt: Evidence for xenolitic contamination. Geofísica Internacional 24, 679-689.

Kumar, A., Sudheer, A.K., Sarin, M.M. (2008): Chemical characteristics of aerosols in MABL of Bay of Bengal and Arabian Sea during spring inter-monsoon: a comparative study. Journal of Earth System Science 117, 325-332. doi: 10.1007/s12040-008-0035-9

Madhavaraju, J., Lee, Y.I. (2009): Geochemistry of the Dalmiapuram Formation of the Uttatur Group (Early Cretaceous), Cauvery basin, southeastern India: Implications on Provenance and Paleo-redox conditions. Revista Mexicana de Ciencias Geológicas 26, 380-394.

Marroquín-Guerra, S.G., Velasco-Tapia, F., Díaz-González, L. (2009): Evaluación estadística de Materiales de Referencia Geoquímica del Centre de Recherches Pétrographiques et Géochimiques (Francia) aplicando un esquema de detección y eliminación de valores des- 
viados. Revista Mexicana de Ciencias Geológicas 26, 530-542.

McLemore, V.T., Leuth, V.W., Pease, T.C., Guilinger, J.R. (1996): Petrology and mineral resources of the Wind mountain laccolith, Cornudas mountains, New Mexico and Texas. Canadian Mineralogist 34, 335-347.

Miller, J.N., Miller, J.C. (2005): Statistics and chemometrics for analytical chemistry. Fifth Edition, Pearson Prentice Hall, Essex CM20 2JE, England: $271 \mathrm{p}$.

Morrison, D.F. (1990): Multivariate statistical methods. Third Edition, McGraw-Hill Publishing Co., New York: 495 p.

Morton Bermea, O. (1990): Zur petrologie des Alkaligesteins-Intrusivkomplexes der Sierra de Picachos (Nuevo León, Mexiko). Diplomarbeit, Universität Karlsruhe, 115 p.

Neave, H.R. (1981): Elementary Statistical Tables. Routledge, London: $49 \mathrm{p}$.

Negendank, J.F.W., Emmermann, R., Krawczyk, R., Mooser, F., Tobschall, H., Werle, D. (1985): Geological and geochemical investigations on the eastern Trans Mexican Volcanic Belt. Geofisica Internacional 24, 477-575.

Nelson, S.A., Gonzalez-Caver, E. (1992): Geology and K-Ar dating of the Tuxtla volcanic field, Veracruz, Mexico. Bulletin of Volcanology 55, 85-96. doi: 10.1007/BF00301122

Nelson, S.A., Gonzalez-Caver, E., Kyser, T.K. (1995): Constraints on the origin of alkaline and calc-alkaline magmas from the Tuxtla Volcanic Field, Veracruz, Mexico. Contributions to Mineralogy and Petrology 122, 191-211. doi: 10.1007/s004100050121

Nick, K. (1988): Mineralogische, Geochemische und Petrographische Untersuchungen in der Sierra de San Carlos (Mexiko). Doctoral thesis, Universitaet (TH) Fridericiana Karlsruhe.

Orozco-Esquivel, M.T. (1995): Zur Petrologie des Vulkangebietes von Palma-Sola, Mexiko. Ein Beispiel fuer den Uebergang von anorogenem zu orogenem Vulkanismus. Doctoral thesis, Universitaet Karlsruhe, $167 \mathrm{p}$.

Orozco-Esquivel, T., Petrone, C.M., Ferrari, L., Tagami, T., Manetti, P. (2007): Geochemical and isotopic variability in lavas from the eastern Trans-Mexican Volcanic Belt: slab detachment in a subduction zone with varying dip. Lithos 93, 149-174. doi: 10.1016/j. lithos.2006.06.006

Pandarinath, K. (2009a): Evaluation of geochemical sedimentary reference materials of the Geological Survey of Japan (GSJ) by an objective outlier rejection statistical method. Revista Mexicana de Ciencias Geológicas 26, 638-646.

Pandarinath, K. (2009b): Clay minerals in SW Indian continental shelf sediments cores as indicators of provenance and paleomonsoonal conditions: a statistical approach. International Geology Review 51, 145-165. doi: 10.1080/00206810802622112

Pandarinath, K., Verma, S.K. (2013): Application of four sets of tectonomagmatic discriminant function based diagrams to basic rocks from northwest Mexico. Journal of Iberian Geology, 181-195. doi: 10.5209/rev_JIGE.2013.v39.n1.41758.

Polat, A., Appel, P.W.U., Fryer, B., Windley, B., Frei, R., Samson, I.M., Huang, H. (2009a): Trace element systematics on the Neoarchean Fiskenæsset anorthosite complex and associated meta-volcanic rocks, SW Greenland: evidence for a magmatic origin. Precambrian Research 175, 87-115. doi: 10.1016/j.precamres.2009.09.002

Polat, A., Frei, R., Fryer, B., Appel, P.W.U. (2009b): The origin of geochemical trends and Eoarchean (ca. $3700 \mathrm{Ma}$ ) zircons in Mesoarchean (ca. $3075 \mathrm{Ma}$ ) ocelli-hosting pillow basalts, Ivisaartog greenstone belt, SW Greenland: evidence for crustal contamination versus crustal recycling. Chemical Geology 268, 248-271. doi: 10.1016/j.chemgeo.2009.09.004

Polat, A., Fryer, B.J., Appel, P.W.U., Kalvig, P., Kerrich, R., Dilek, Y., Yang, Z. (2011): Geochemistry of anorthositic differentiated sills in the Archean ( 2970Ma) Fisken $\tilde{A}_{\mid}^{\prime}$ sset Complex, SW Greenland:
Implications for parental magma compositions, geodynamic setting, and secular heat flow in arcs. Lithos 123, 50-72. doi: 10.1016/j. lithos.2010.12.003

Rajesh, H.M. (2007): The petrogenetic characterization of intermediate and silicic charnockites in high-grade terrains: a case study from southern India. Contributions to Mineralogy and Petrology, 154: 591-606. doi: 10.1007/s00410-007-0211-y

Potter, L.S. (1996): Chemical variation along strike in feldspathoidal rocks of the Eastern Alkalic Belt, Trans-Pecos magmatic province, Texas and New Mexico. Canadian Mineralogist 34, 241-264.

Ramakrishnan, M. (2009): Precambrian mafic magmatism in the Western Dharwar Craton, southern India. Journal of Geological Society of India 73, 101-116. doi: 10.1007/s12594-009-0006-Z

Ramírez Fernández, J.A. (1996): Zur petrogenese des alkalikomplexes der Sierra de Tamaulipas, NE-Mexiko. Doctoral thesis, Albert-Ludwigs-Universitaet, $316 \mathrm{p}$.

R Development Core Team (2009): R: A language and environment for statistical computing. URL http:/www.R/project.org ed.: R Foundation for Statistical Computing, Vienna, Austria.

Rencher A.C. (2002): Methods of Multivariate Analysis. Second Edition, Wiley-Interscience, New York: 708 p.

Robin, C. (1976): Présence simultanée de magmatismes de significations tectoniques opposées dans l'Est du Mexique. Bulletin de la Societe Geologique de France 18, 1637-1645.

Robin, C., Tournon, J. (1978): Spatial relations of andesitic and alkaline provinces of Mexico and Central America. Canadian Journal of Earth Sciences 15, 1633-1641. doi: 10.1139/e78-167

Rodríguez, S.R., Morales-Barrera, W., Layer, P., González-Mercado, E. (2010): A Quaternary monogenetic volcanic field in the Xalapa region, eastern Trans-Mexican Volcanic Belt: geology, distribution and morphology of the volcanic event. Journal of Volcanology and Geothermal Research 197, 149-166. doi: 10.1016/j.jvolgeores.2009.08.003

Rossotti, A., Carrasco-Nuñez, G., Rosi, M., Di Muro, A. (2006): Eruptive dynamics of the "Citlaltépetl pumice" at Citlaltépetl volcano, eastern Mexico. Journal of Volcanology and Geothermal Research 158, 401-429. doi: 10.1016/j.jvolgeores.2006.07.008

Santoyo, E., Verma, S.P. (2003): Determination of lanthanides in synthetic standards by reversed-phase high performance liquid chromatography with the aid of a weighted least-squares regression model: estimation of method sensitivities and detection limits. Journal of Chromatography A 997, 171-182. doi: 10.1016/S00219673(03)00624-1

Sheth, H.C. (2008): Do major oxide tectonic discrimination diagrams work? Evaluating new log-ratio and discriminant-analysis-based diagrams with Indian Ocean mafic volcanics and Asian ophiolites. Terra Nova 20, 229-236. doi: 10.1111/j.1365-3121.2008.00811.x

Siebert, L., Carrasco-Núñez, G. (2002): Late-Pleistocene to precolumbian behind-the-arc mafic volcanism in the eastern Mexican Volcanic Belt; implications for future hazards. Journal of Volcanology and Geothermal Research 115, 179-205. doi: 10.1016/S03770273(01)00316-X

Slovenec, D., Lugovic, B., Vlahovic, I. (2010): Geochemistry, petrology and tectonomagmatic significance of basaltic rocks from the ophiolite mélange at the NW External-Internal Dinarides junction (Croatia). Geologica Carpathica 61, 273-292. doi: 10.2478/ v10096-010-0016-1

Tamisier-Korolak, S.L., Le Potier, I., Barlet, O., Czok, M. (1999): Analysis of anions in aqueous samples by ion chromatography and capillary electrophoresis. A comparative study of peak modeling and validation criteria. Journal of Chromatography A 852, 487-498. doi: 10.1016/S0021-9673(99)00650-0

Torres-Alvarado, I.S., Smith, A.D., Castillo-Roman, J. (2011): Sr, Nd and $\mathrm{Pb}$ isotopic and geochemical constraints for the origin of mag- 
mas in Popocatepetl volcano (central Mexico) and their relationship with the adjacent volcanic fields. International Geology Review 53, 84-115. doi: 10.1080/00206810902906738

Treviño-Cázares, A., Ramírez-Fernández, J.A., Velasco-Tapia, F., Rodríguez-Saavedra, P. (2005): Mantle xenoliths and their host magmas in the Eastern Alkaline Province (NE Mexico). International Geology Review 47, 1260-1286. doi: 10.2747/00206814.47.12.1260

Velasco-Tapia, F., Guevara, M., Verma, S.P. (2001): Evaluation of concentration data in geochemical reference materials. Chemie der Erde 61, 69-91.

Verma, M.P. (2004): A revised analytical method for HCO3- and $\mathrm{CO}^{2-}$ determinations in geothermal waters: an assessment of IAGC and IAEA interlaboratory comparisons. Geostandards and Geoanalytical Research 28, 391-409. doi: 10.1111/j.1751-908X.2004. tb00758.x

Verma, M.P. (2008): IAGC and IAEA interlaboratory comparisons of geothermal water chemistry: the propagation of uncertainty in the reservoir $\mathrm{pH}$ calculation. Geostandards and Geoanalytical Research 32, 317-330. doi: 10.1111/j.1751-908X.2008.00832.x

Verma, M.P. (2013): IAEA Inter-laboratory comparisons of geothermal water chemistry: critiques on analytical uncertainty, accuracy, and geothermal reservoir modelling of Los Azufres, Mexico. Journal of Iberian Geology, 57-72. doi:10.5209/rev_JIGE.2013.v39. n1.41748.

Verma, S.K., Verma, S.P. (2012): Identification of Archaean plate tectonic processes from multidimensional discrimination diagrams and probability calculations. International Geology Review 55, 225-248

Verma, S.K., Pandarinath, K., Verma, S.P. (2012): Statistical evaluation of tectonomagmatic discrimination diagrams for granitic rocks and proposal of new discriminant-function-based multi-dimensional diagrams for acid rocks. International Geology Review 54, $325-$ 347. doi: $10.1080 / 00206814.2010 .543784$

Verma, S.P. (1997): Sixteen statistical tests for outlier detection and rejection in evaluation of International Geochemical Reference Materials: example of microgabbro PM-S. Geostandards Newsletter. The Journal of Geostandards and Geoanalysis 21, 59-75. doi: 10.1111/j.1751-908X.1997.tb00532.x

Verma, S.P. (1998): Improved concentration data in two international geochemical reference materials (USGS basalt BIR-1 and GSJ peridotite JP-1) by outlier rejection. Geofísica Internacional 37, 215 250.

Verma, S.P. (2005): Estadistica básica para el manejo de datos experimentales: aplicación en la Geoquímica (Geoquimiometría). UNAM, México, D.F.: 186 p.

Verma, S.P. (2006): Extension-related origin of magmas from a garnet-bearing source in the Los Tuxtlas volcanic field, Mexico. International Journal of Earth Sciences 95, 871-901. doi: 10.1007/ s00531-006-0072-z

Verma, S.P. (2009): Evaluation of polynomial regression models for the Student $t$ and Fisher F critical values, the best interpolation equations from double and triple natural logarithm transformation of degrees of freedom up to 1000 , and their applications to quality control in science and engineering. Revista Mexicana de Ciencias Geológicas 26, 79-92.

Verma, S.P. (2010): Statistical evaluation of bivariate, ternary and discriminant function tectonomagmatic discrimination diagrams. Turkish Journal of Earth Sciences 19, 185-238.

Verma, S.P. (2012a): Geochemometrics. Revista Mexicana de Ciencias Geológicas 29, 276-298.

Verma, S.P. (2012b): Application of multi-dimensional discrimination diagrams and probability calculations to acid rocks from Portugal and Spain. Comunicações Geológicas 99, 79-93.
Verma, S.P. (2013): Application of fifty multi-dimensional discrimination diagrams and significance tests: deciphering compositional similarities and differences between Hawaiian and Icelandic volcanism. International Geology Review, in press, doi:10.1080/0020 6814.2013.788239

Verma, S.P., Agrawal, S. (2011): New tectonic discrimination diagrams for basic and ultrabasic volcanic rocks through log-transformed ratios of high field strength elements and implications for petrogenetic processes. Revista Mexicana de Ciencias Geológicas 28, 24-44.

Verma, S.P., Cruz-Huicochea, R. (2013): Alternative approach for precise and accurate Student's t critical values in geosciences with special application to geochemical reference materials of granites G-1 and G-2 from U.S.A. and basic rocks from the Canary and Azores Islands. Journal of Iberian Geology 39 (1), 31-56. doi:10.5209/ rev_JIGE.2013.v39.n1.41747.

Verma, S.P., Díaz-González, L. (2012): Application of the discordant outlier detection and separation system in the Geosciences. International Geology Review 54, 593-614. doi: $10.1080 / 00206814.2011 .569402$

Verma, S.P., Quiroz-Ruiz, A. (2006a): Critical values for six Dixon tests for outliers in normal samples up to sizes 100, and applications in science and engineering. Revista Mexicana de Ciencias Geológicas 23, 133-161.

Verma, S.P., Quiroz-Ruiz, A. (2006b): Critical values for 22 discordancy test variants for outliers in normal samples up to sizes 100 , and applications in science and engineering. Revista Mexicana de Ciencias Geológicas 23, 302-319.

Verma, S.P., Quiroz-Ruiz, A. (2008): Critical values for 33 discordancy test variants for outliers in normal samples for very large sizes of 1,000 to 30,000. Revista Mexicana de Ciencias Geológicas 25, 369-381.

Verma, S.P., Quiroz-Ruiz, A. (2011): Corrigendum to Critical values for 22 discordancy test variants for outliers in normal samples up to sizes 100, and applications in science and engineering [Rev. Mex. Cienc. Geol., 23 (2006), 302-319]. Revista Mexicana de Ciencias Geológicas 28, 202.

Verma, S.P., Rivera-Gómez, M.A. (2013): New computer program TecD for tectonomagmatic discrimination from discriminant function diagrams for basic and ultrabasic magmas and its application to ancient rocks. Journal of Iberian Geology 39 (1), 31-56. doi:10.5209/rev_JIGE.2013.v39.n1.41747.

Verma, S.P., Verma, S.K. (2013): First fifteen probability-based multidimensional discrimination diagrams for intermediate magmas and their roboustness against post-emplacement compositional changes and petrogenetic processes. Turkish Journal of Earth Sciences, in press.

Verma, S.P., Salazar-V., A., Negendank, J.F.W., Milán, M., NavarroL., I., Besch, T. (1993): Características petrográficas y geoquímicas de elementos mayores del campo volcánico de Los Tuxtlas, Veracruz, México. Geofísica Internacional 32, 237-248.

Verma, S.P., Torres-Alvarado, I.S., Sotelo-Rodríguez, Z.T. (2002): SINCLAS: standard igneous norm and volcanic rock classification system. Computers \& Geosciences 28, 711-715. doi: 10.1016/ S0098-3004(01)00087-5

Verma, S.P., Guevara, M., Agrawal, S. (2006): Discriminating four tectonic settings: five new geochemical diagrams for basic and ultrabasic volcanic rocks based on log-ratio transformation of majorelement data. Journal of Earth System Science 115, 485-528. doi: 10.1007/BF02702907

Verma, S.P., Quiroz-Ruiz, A., Díaz-González, L. (2008): Critical values for 33 discordancy test variants for outliers in normal samples up to sizes 1000 , and applications in quality control in Earth Sciences. Revista Mexicana de Ciencias Geológicas 25, 82-96. 
Verma, S.P., Díaz-González, L., González-Ramírez, R. (2009): Relative efficiency of single-outlier discordancy tests for processing geochemical data on reference materials. Geostandards and Geoanalytical Research 33, 29-49. doi: 10.1111/j.1751-908X.2009.00885.x

Verma, S.P., Pandarinath, K., Verma, S.K., Agrawal, S. (2013a): Fifteen new discriminant-function-based multi-dimensional robust diagrams for acid rocks and their application to Precambrian rocks. Lithos 168-169, 113-123. doi.org/10.1016/j.lithos.2013.01.014

Verma, S.P., Cruz-Huicochea, R., Díaz-González, L. (2013b): Univariate data analysis system: deciphering mean compositions of island and continental arc magmas, and influence of the underlying crust. International Geology Review, in press. doi: 10.1080/00206814.2013.810363

Walker, J.T., Maddan, S. (2005): Statistics in Criminology and Criminal Justice Analysis and Interpretation. Second Edition, Jones and Bartlett Publishers, Sudbury, Mass., USA: 427 p.

Wang, L., Li, J., Shi, Y., Zhang, L. (2010): The identification and pre- diction of Carboniferous volcanic rocks in Dixi area, Junggar basin. Acta Petrologica Sinica 26, 242-254.

Wani, H., Mondal, M.E.A. (2011): Evaluation of provenance, tectonic setting, and paleoredox conditions of the Mesoproterozoic-Neoproterozoic basins of the Bastar craton, Central Indian Shield: Using petrography of sandstones and geochemistry of shales. Lithosphere 3, 143-154. doi: 10.1130/L74.1

Wilks, S.S. (1963): Multivariate statistical outliers. Sankhyã A15, 407-426.

Zeyrek, M., Ertekin, K., Kacmaz, S., Seyis, C., Inan, S. (2010): An ion chromatography method for the determination of major anions in geothermal water samples. Geostandards and Geoanalytical Research 34, 67-77. doi: 10.1111/j.1751-908X.2009.00020.x

Zhang, Z., Zhao, G., Santosh, M., Wang, J., Dong, X., Shen, K. (2010): Late Cretaceous charnockite with adakitic affinities from the Gangdese batholith, southeastern Tibet: Evidence for Neo-Tethyan mid-ocean ridge subduction? Gondwana Research 17, 615-631. doi: 10.1016/j.gr.2009.10.007

\section{Appendix A - Supplementary material}

Tables 1 to 32 cited in this paper can be downloaded from http://revistas.ucm.es/index.php/JIGE/ 